\title{
Effects of Pellet Die Heat and Pressure on Pellet Quality and Broiler Lysine Utilization
}

\author{
Kevin Joseph Shipe
}

West Virginia University

Follow this and additional works at: https://researchrepository.wvu.edu/etd

\section{Recommended Citation}

Shipe, Kevin Joseph, "Effects of Pellet Die Heat and Pressure on Pellet Quality and Broiler Lysine Utilization" (2012). Graduate Theses, Dissertations, and Problem Reports. 3522.

https://researchrepository.wvu.edu/etd/3522

This Thesis is protected by copyright and/or related rights. It has been brought to you by the The Research Repository @WVU with permission from the rights-holder(s). You are free to use this Thesis in any way that is permitted by the copyright and related rights legislation that applies to your use. For other uses you must obtain permission from the rights-holder(s) directly, unless additional rights are indicated by a Creative Commons license in the record and/ or on the work itself. This Thesis has been accepted for inclusion in WVU Graduate Theses, Dissertations, and Problem Reports collection by an authorized administrator of The Research Repository @ WVU. For more information, please contact researchrepository@mail.wvu.edu. 
Effects of Pellet Die Heat and Pressure on

Pellet Quality and Broiler Lysine Utilization

\author{
Kevin Joseph Shipe
}

Thesis submitted to the Davis College of Agriculture, Natural Resources, and Design

at

West Virginia University

in partial fulfillment of the requirements

for the degree of

\author{
Master of Science \\ in
}

Nutrition and Food Science

Joseph S. Moritz, Ph.D., Chair

Kenneth P. Blemings, Ph.D.

K. Marie Krause, Ph.D.

\title{
Division of Animal and Nutritional Sciences \\ Morgantown, West Virginia
}

2012

Keywords: lysine, feed manufacture, pellet quality, true amino acid digestibility, Maillard reaction, furfural

Copyright 2012 Kevin Joseph Shipe 


\begin{abstract}
The objective of this study was to identify feed manufacture techniques that alter lysine availability as indicated by broiler performance in the finishing phase, diet furfural content, and true amino acid digestibility. Production rate, pellet die specification, and level of mixer-added fat (MAF) influence feed exposure to pellet die frictional heat and pressure that may alter chemical structure of ingredients. Lysine has been indicated as a nutrient with potential to be structurally altered, especially in the presence of heat and reducing sugars, as in Maillard reactions; decreasing nutrient availability. A practical diet containing $7.5 \%$ bakery by-product meal and $0.13 \%$ lysine $\mathrm{HCl}$ was formulated to $90 \%$ of the lysine recommendation by CobbVantress to be below the perceived safety margin associated with breeder recommendations and best demonstrate lysine availability differences when manufactured and fed. This diet was utilized in a $2 \times 2 \times 2$ factorial design that evaluated the main effects of production rate ( 0.5 or 0.8 tonne/hr), pellet mill die thickness $(38.1$ or $44.5 \mathrm{~mm})$, and MAF level $(0.5$ or $3 \%)$ on feed manufacture, broiler performance, and processing yield. Two additional treatments: unprocessed mash and double pelleted (exposed twice to 0.5 tonne/hr production using a $4.5 \mathrm{~mm}$ die after 0.5\% MAF) were also manufactured and fed. All diets, excluding mash, were steam conditioned at $82^{\circ} \mathrm{C}$ and ground prior to feeding. Pellet mill electrical energy usage, pellet quality, and bulk density were increased with 0.5 tonne/hr production rate, $44.5 \mathrm{~mm}$ pellet die, and $0.5 \% \mathrm{MAF}$ processing treatments $(\mathrm{P}=0.0001)$; indicating greater feed exposure to pellet die frictional heat and pressure. Bird performance and carcass characteristics were not affected by main effects $(\mathrm{P}>0.05)$; however, contrasts demonstrated that mash fed birds had decreased feed conversion ratio (FCR) compared with double pelleted fed birds, with birds fed diets from the factorial treatments being intermediate $(\mathrm{P}<0.05)$. To determine if the mechanism of action responsible for the FCR effects included lysine digestibility, diets were analyzed for furfural, an intermediate of
\end{abstract}


the Maillard reaction pathway, and assessed for true amino acid digestibility using cecectomized roosters. Furfural concentration was not altered due to processing treatment $(\mathrm{P}>0.05)$. In addition, no differences in lysine digestibility or the digestibility of any other tested amino acid were apparent $(\mathrm{P}>0.05)$. Therefore, lysine availability, as assessed with this specific methodology, does not appear to be decreased due to pelleting. 


\begin{abstract}
AKNOWLEDGEMENTS
Without my family, friends, and colleagues and their support, I would have never come this far or conquered so much. For this I am forever grateful. I would like to thank Dr. Joseph Moritz for the honor of working under his direction and introducing me to so many wonderful people. It was through this opportunity that I was able to meet numerous individuals in the poultry industry that will undoubtedly enrich my career. I would also like to thank my committee members, Drs. Kenneth Blemings and Marie Krause. Their guidance and assistance enhanced my research and overall graduate training. Research is labor-intensive, and without the help of Ashley Evans, Kelley Wamsley, Brittany Swiger, Laurel Shires, and others this would not have been possible. I thank all the faculty and staff at West Virginia University for all the assistance they have provided over the years, especially those at the WVU Animal Science Farm. I would like to thank my parents, Kent and Lisa Shipe; my grandparents, Freel and Eleanor Shipe and Arlene Davis; my brother, Jason; and my girlfriend, Bethany. I truly appreciate their continued love and support.
\end{abstract}




\section{TABLE OF CONTENTS}

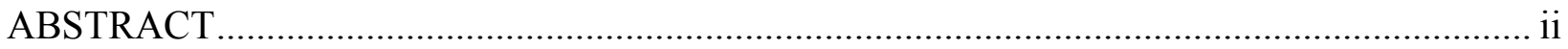

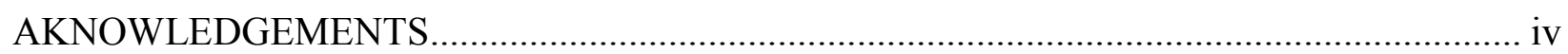

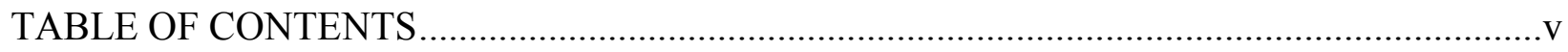

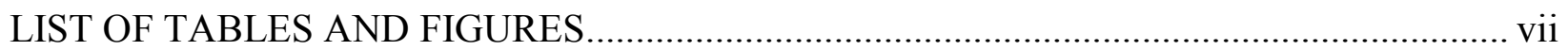

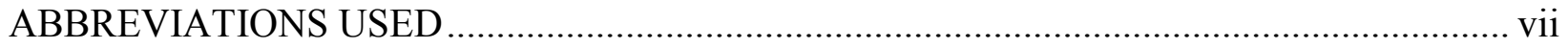

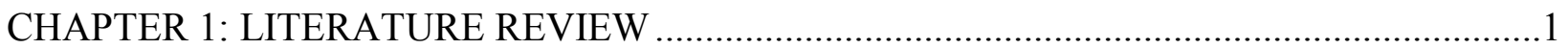

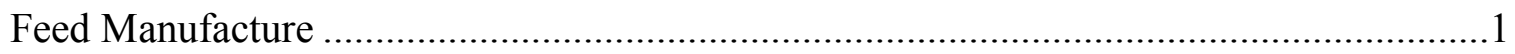

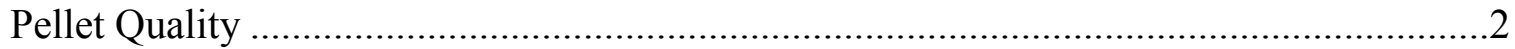

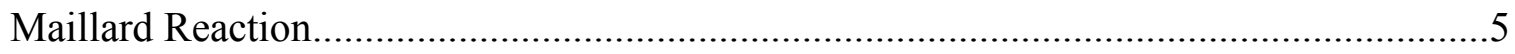

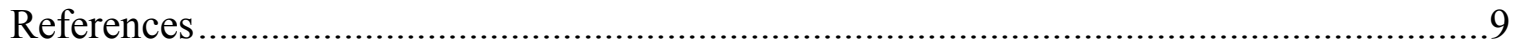

CHAPTER 2: EFFECTS OF PELLET DIE HEAT AND PRESSURE ON PELLET QUALITY

AND BROILER LYSINE UTILIZATION ……………....................................................12

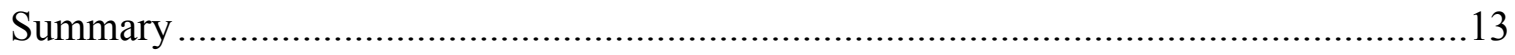

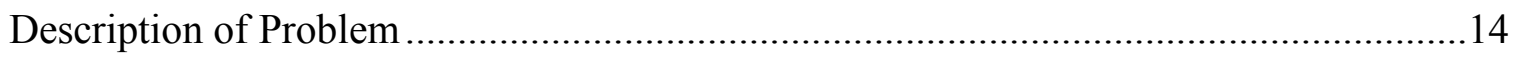

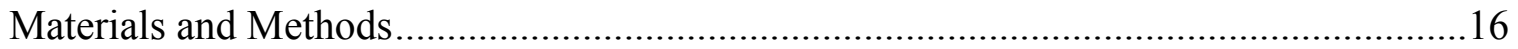

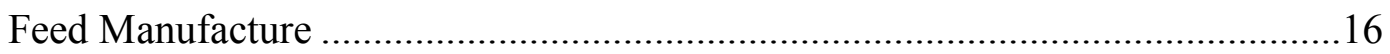

Broiler Performance ......................................................................................18

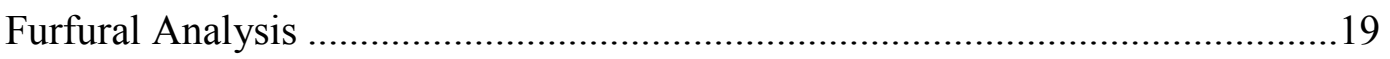

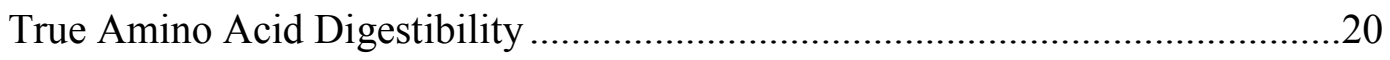

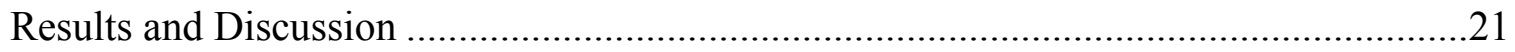

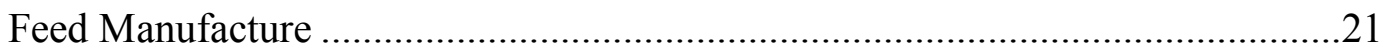

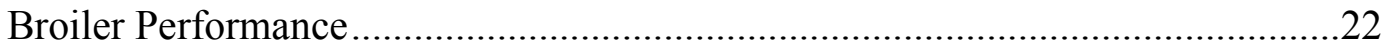


Furfural Analysis

True Amino Acid Digestibility ...... .23

Conclusions and Applications...... .24

References .25

Table 1. 23-42d broiler finisher diet formulation .29

Table 2. 23-42d broiler finisher feed manufacture variables 30

Table 3. 23-42d male broiler chick performance .32

Table 4. 23-42d male broiler chick carcass characteristics. .34

Table 5. Furfural content of feed manufactured with various techniques .36

Table 6. True digestibilities of amino acids in broiler feed manufactured with various techniques .37

Figure 1. Maillard reaction ..6 


\section{LIST OF TABLES AND FIGURES}

Table 1. 23-42d broiler finisher diet formulation ...................................................29

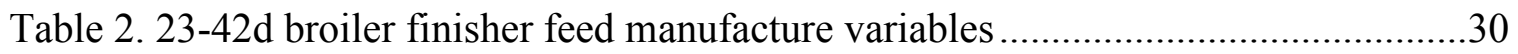

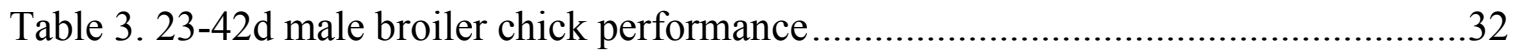

Table 4. 23-42d male broiler chick carcass characteristics.............................................34

Table 5. Furfural content of feed manufactured with various techniques ........................36

Table 6. True digestibilities of amino acids in broiler feed manufactured with various

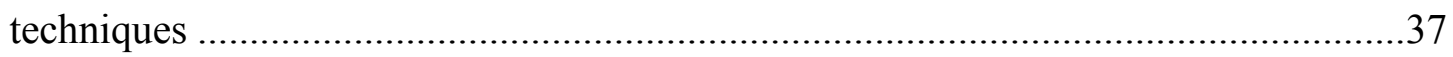

Figure 1. Maillard reaction .................................................................................. 


\section{Chapter 1} \\ CREEU $=$ conditioner relative electrical energy usage \\ FCR - Feed conversion ratio \\ FI - Feed intake \\ LWG - Live weight gain \\ MAF $=$ mixer-added fat \\ MPDI - Modified pellet durability index \\ PDI - Pellet durability index \\ PREEU - pellet mill relative electrical energy usage
}

ABBREVIATIONS USED

\title{
Chapter 2
}

D - dark

d - day

DDGS - dried distillers grains with solubles

Dgw - median size: particle diameter at $50 \%$ probability of a size distribution curve, equivalent

to geometric mean diameter

FCR - feed conversion ratio

FI - feed intake

L - light

LWG - live weight gain

MPDI - modified pellet durability index

PDI - pellet durability index

Sgw - log-normal standard deviation 


\section{CHAPTER 1: LITERATURE REVIEW}

$\underline{\text { Feed Manufacture }}$

Pelleting feed is an energy intensive process that results in animal performance benefits that can justify the cost of production if feed form integrity is maintained without detriment to nutritional quality (Behnke, 1996; Moritz and Lilly, 2011). For this reason, more than $80 \%$ of U.S. non-ruminant feed is pelleted (Behnke, 2001). The process of pelleting feed has multiple steps. Mash feed (a mix of dry, ground ingredients) is first conditioned with saturated steam. Conditioning allows feed to become more pliable to aid in pellet formation. Conditioning subjects feed to temperatures that typically range between 70 and $93{ }^{\circ} \mathrm{C}$. During conditioning, feed is conveyed towards a pelleting chamber. In the pelleting chamber feed is pressed into, and extruded through a pellet die. Extrusion occurs due to conditioned feed being pressed between rolls and the pellet die. This occurs with each rotation of the die or roll system depending on the type of pellet press utilized. As conditioned feed is extruded through the pellet die it is subjected to high frictional force and pressure. Frictional force and pressure increase as conditioning temperature decreases. However, accurate measures of temperature increase or decrease of extruded pellets is difficult to obtain due to the flash-off of heat that occurs immediately after pellet extrusion through the die. Anecdotally, feed that is conditioned at a low temperature i.e. $70^{\circ} \mathrm{C}$ can pick up approximately $1{ }^{\circ} \mathrm{C}$ when extruded through a pellet die. However, it is important to note that temperature increase across the die may be dependent on additional variables, such as rate of feed conveyance, die thickness, and diet composition (Moritz, 2011). Once the compressed feed is extruded beyond the outer surface of the die, it takes on the form of a pellet. A stationary knife then cuts off the pellet at a desired length. Finally, pellets are cooled and/or dried to remove excess moisture which could promote the growth of mold as well as 
dilute nutrient content. Pelleted feed is typically delivered to a farm for short-term storage prior to consumption rather than stored at the mill.

Pelleting feed has been described to provide performance improvements due to decreased feed wastage, reduced selective feeding, decreased ingredient segregation, decreased energy expenditure for feed apprehension, improved palatability, increased digestibility, and thermal modification of starch and protein (Behnke, 1994). Pelleted diets improve broiler and swine performance when compared to mash diets (Hussar and Robblee, 1962; Baird, 1973; Wondra, 1995; Medel, 2003). However, the magnitude of benefit has been shown to be dependent upon pellet quality (Lilly et. al., 2011).

\section{Pellet Quality}

According to the widely cited proceedings paper by Reimer (1992), pellet quality can be attributed to the following factors: diet formulation (40\%), conditioning (20\%), particle size (20\%), die specification (15\%), and drying/cooling (5\%). However, there is little peer-review

evidence to support these variable contributions. In modern feed manufacture, pellet quality has been suggested to be affected more by equipment than by diet formulation (Thomas, 1997). Buchanan et al. (2010) found that die length to diameter ratio plays a substantial role in pellet quality. In pelleting a corn-soy based broiler diet, it was reported by Cutlip et al. (2008) that steam-conditioning at $93^{\circ} \mathrm{C}$ as compared to $82^{\circ} \mathrm{C}$ improved PDI by four percentage points $(\mathrm{P}=0.0001)$ and decreased FCR by 20 points $(\mathrm{P}=0.0321)$. Gehring et al. (2011) reported decreased pellet mill energy usage $(\mathrm{P}<0.0001)$, increased conditioner energy usage $(\mathrm{P}=0.018)$, and decreased motor load amperage $(\mathrm{P}<0.0001)$ when pelleted formulations included increased mixer-added fat. Increasing MAF has been shown to lubricate the pellet die (Jones et al., 1995; Cutlip et al., 2008; Briggs et al., 1999). Production rate can dictate retention time of feed within 
the conditioner and pellet die. Retention time is the amount of time feed constituents are exposed to thermo-mechanical interactions. Increasing production rate decreases retention time and thus nutrient binding interactions. The converse is also true.

Proteins reassociate during cooling and bond with a variety of feed constituents (Thomas et al., 1998). Wheat binding properties positively affect pellet quality due to hydration and partial denaturation of the wheat gluten (Wood, 1987). The protein matrix of wheat flour, when moistened, transforms into fibrils that interconnect suspended particles like starch and fiber (Seckinger and Wolf, 1970; Bernardin and Kasarda, 1973). Studies suggest that including plant proteins will improve pellet quality (Stevens, 1987; Briggs et al., 1999; Cavalcanti, 2004). The mechanism(s) responsible for the improvement in binding has yet to be clarified. Diets containing raw soy protein have higher physical pellet quality as compared to those containing denatured soy protein (Wood, 1987); yet corn-derived plant proteins do not provide similar positive effects (Cavalcanti, 2004). With such conflicting results concerning pellet quality due to protein denaturation, more research is needed to elucidate the effects of chemical modification of protein and protein sources resulting from thermo-mechanical forces during feed manufacture.

Few studies have examined whether protein digestibility becomes altered due to manufacture. The few experiments that have examined the changes in protein digestibility before and after processing do not distinguish between the effects of physical structure, reduction or complete elimination of anti-nutritive factors, and protein denaturation. Increased protein digestibility as a result of denaturation as reported by Mauron (1990) is not substantial, if even present. A small, but significant increase in protein digestibility in swine finishing feed when pelleted was reported by Vande Ginste and De Schrijver (1998); however, Carré et al. (1991) reported no improvement in protein digestibility when feeding pellets to broiler chickens. Duodu 
et al. (2002) showed that cooking for 10 minutes at $95^{\circ} \mathrm{C}$ decreased in vitro protein digestibility of sorghum, but not corn. Steam-pelleting sorghum-based diets above $90^{\circ} \mathrm{C}$ may provide enough moist heat to induce disulfide linkages in kafirin, a storage protein found in sorghum, and compromise protein and starch digestibility (Selle et al., 2010). When Abdollahi et al. (2011) steam-conditioned wheat-based broiler diets at 60 and $75^{\circ} \mathrm{C}$, an increase in ileal digestibility of nitrogen as compared to mash ( 0.854 and 0.852 , respectively) resulted. The increase in nitrogen digestibility at $60^{\circ} \mathrm{C}$ was possibly due to protein denaturation, thus inactivation of enzyme inhibitors. This improvement was not present above $90^{\circ} \mathrm{C}(0.835)$ which may have been due to formation of Maillard products. It was also observed that the nitrogen digestibility of the mash (0.855) was greater than that of pellets $(0.831)$. This suggests that pelleting, in general, has a deleterious effect on digestibility. The effect of pelleting on starch digestibility in wheat is well documented (Svihus and Hetland, 2001; Svihus, 2001). Conversely, research examining the effect of pelleting on protein digestibility is limited.

Factors that improve pellet quality may decrease nutrient availability. For example, high production rate and high MAF decreases pellet quality; however, this processing technique improves amino acid digestibility for 1-39d male turkey poults (Lilly et al., 2011). Smith and Circle (1972) specifically cite reduced lysine digestibility due to the Maillard reaction when reporting the negative effect of steam conditioning on the availability of amino acids. Loop et al. (2010) saw numerical decreases in enzyme retention when conditioning temperature was increased from 77 to $82^{\circ} \mathrm{C}$. Beaman et al. (2010) reported that an enzyme cocktail that was effective when utilized in mash feeds was ineffective when feed was conditioned at 88 or $93^{\circ} \mathrm{C}$. Yet, the enzyme cocktail was not effective at 71 or $77^{\circ} \mathrm{C}$ even when MAF was manipulated and a thin die used. Decreasing MAF significantly increases PDI and MPDI (Gehring, 2009); however 
increasing MAF improves exogenous enzyme efficacy and subsequent broiler performance, and reduces electrical energy used in the pelleting process. Interestingly, potential negative effects of pelleting on protein digestibility are not commonly considered by commercial nutritionists and feed manufacturers associated with feeding poultry.

$\underline{\text { Maillard Reaction }}$

The Maillard reaction refers to a series of reactions that occur in vitro and in vivo (Panigrahy et al., 1976; Cannon and Davison, 1978; Iqbal et al., 1999; Fayle and Gerrard, 2002). Maillard reaction products provide human foods with desirable aromas and colors (Ames, 1998; Martins et al., 2001). Yet, these reactions are associated with nutritional detriment (Martins et al., 2001), particularly when production animal feeds and thermally processed feed ingredients are considered (Parsons et al, 1992, Anderson-Haferman et al, 1993; Zhang and Parsons, 1994). Processing variables associated with increasing thermal effects on feed that may potentially induce Maillard reactions include diet formulation, steam conditioning, and die specification. Mauron (1981) described the Maillard reaction occurring in three stages: the initial Maillard reaction, the advanced Maillard reaction, and the final Maillard reaction.

The initial Maillard reaction involves the condensation of an amine and a carbonyl compound to form a Schiff base, and subsequent isomerization to form Amadori or Heyns products (Dills, 1993). The reaction typically occurs between a protein and a reducing sugar and primarily involves the $\varepsilon$-amino group of lysine (Dills, 1993), but may also involve the $\alpha$-amino groups of terminal amino acids (Dills, 1993; Martin et al., 2001) or crystalline amino acids used in broiler diets. The Schiff base cyclizes to form an N-substituted glycosylamine that undergoes subsequent Amadori or Heyns rearrangement (Dills, 1993). 
The advanced Maillard reaction refers to the production of intermediates and the initial flavor and aroma compounds (Mauron, 1981; Hodge, 1953). Amadori and Heyns products decompose to form degradation products that can further react with other amino acids or reducing sugars (Hodge, 1953; Martins et al., 2001). The most apparent nutritional consequence of the Maillard reaction is the loss of amino acids and sugars (Dills, 1993). Glycosylamines hydrolysate to yield the free amino acid and sugar but Amadori and Heyns products do not (Dills, 1993). Even though the advanced Maillard reaction products do not yield available amino acids or sugars, many are absorbed as isopeptide moieties and are then excreted in the urine (Valle-Riestra and Barnes, 1969; Ford and Shorrock, 1971; Hurrel and Carpenter, 1981).

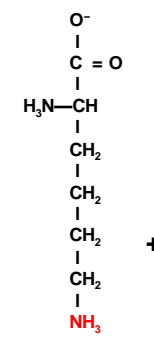

Lysine

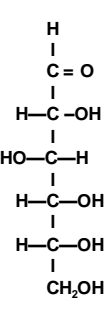

Glucose

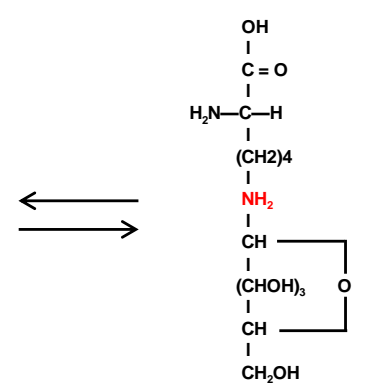

N-glycosylamine

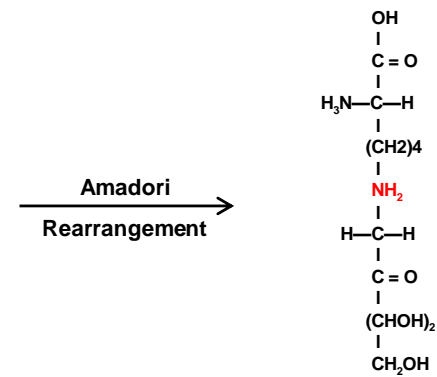

1-amino-1-deoxy-2-ketose
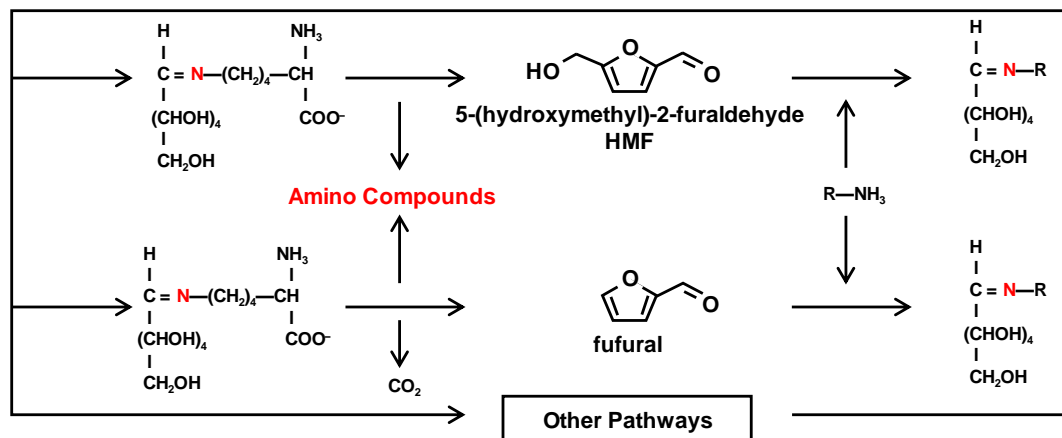
$(\mathrm{CHOH})_{4}$ $\mathrm{CH}_{2} \mathrm{OH}$

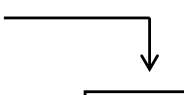
$\mathrm{HMF}$
$\mathrm{R}-\mathrm{NH}_{3}$
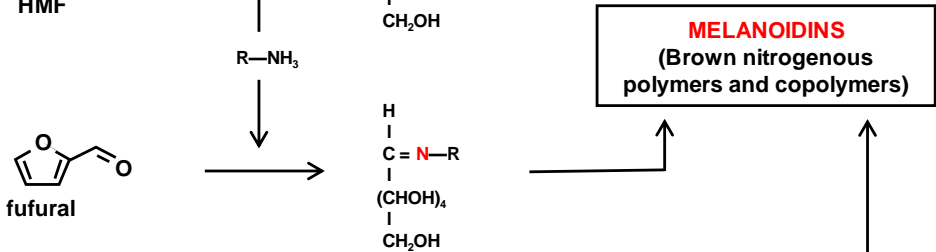

Figure 1. Maillard reaction 
In the final Maillard reaction stage, deoxysones and Strecker degradation products are formed and are the precursors for melanoides, brown polymers and co-polymers that have high molecular weights (Ames, 1998; Kitts, 2007). Increased non-enzymatic browning has been associated with the reduced nutritional quality of thermally-processed feed ingredients such as dried distillers grains with solubles (Fastinger et al, 2006) and canola meal (Newkirk and Classen, 2002). Reduced nutritive value of poultry feeds caused by increased digesta viscosity (Antoniou et al., 1981; Choct and Annison, 1990; Bedford, 2000) and reduced luminal nutrient and enzyme diffusion may be due to soluble non-starch polysaccharides. Similarly, melanoides may increase digesta viscosity, but only slightly (Manzocco and Maltini, 1999). In broilers and turkeys, increased digesta viscosity decreases passage rate, producing wet, sticky excreta. Subsequently, floor conditions suffer, creating health challenges for the entire flock of birds.

Dale (1992) performed multiple experiments examining the interaction between free sugars and free amines in the presence of moist heat. Lysine availability was assayed by chemical means and was not found to demonstrate consistent differences $(\mathrm{P}>0.05)$. In vivo, diets containing graded levels of free lysine and static $6 \%$ dried bakery product when fed from $4-18 \mathrm{~d}$, showed that pellets improved weight gain and FCR as compared to mash $(\mathrm{P}<0.05)$. This was likely due to a feed form effect that would allow the birds to consume enough feed to overcome any nutrient detriment created in the pelleting process (Bayley et al., 1968).

Steam conditioning has potential to change viscosity. The quantity of soluble fiber does not change during feed processing (Pettersson et al., 1991; Inborr and Bedford, 1994; Cowieson et al., 2005b; Garcia et al., 2008; Abdollahi et al., 2010), but viscosity may change. Viscosity depends on soluble carbohydrate concentration and the degree of polymerization of carbohydrate (Izydorczyk and Biliaderis, 1992; Cowieson et al., 2005). Viscosity can be high even when the 
concentration of soluble polysaccharide is low, if the polysaccharides present have sufficient molecular weight (Cowieson et al., 2005). Viscosity of diets conditioned at high temperatures may increase regardless of the concentration of the soluble carbohydrates due to increased polymerization. Again, increased digesta viscosity leads to poor floor condititions that create health challenges for birds.

The relationship between feed manufacture, pellet quality, and nutrient availability is complicated and not well defined. The following experiment attempts to elucidate part of this relationship. Of particular interests are the effects of frictional heat and pressure in the pellet die on lysine digestibility. 


\section{REFERENCES AND NOTES}

Ames, J. M. 1990. Control of the Maillard reaction in food systems. Trends Food Sci. Technol. 1:150-154.

Anderson-Haferman, J. C., Y. Zhang and C.M. Parsons. 1993. Effects of processing on the nutritional quality of canola meal. Poult. Sci. 72:326-333.

Baird, D. M. 1973. Influence of Pelleting Swine Diets on Metabolizable Energy, Growth and Carcass Characteristics. J. Anim. Sci. 36:516-521.

Bayley H. S., J. D. Summers, and S. J. Slinger. 1968. The influence of steam pelleting conditions on the nutritional value of chick diets. Poult. Sci. 47:931-939.

Beaman, K. R. Determining efficacy of a thermally processed exogenous enzyme cocktail for broilers. MS thesis. West Virginia University, Morgantown, 2009. Dissertations and Theses. Web. 15 May 2012.

Behnke, K. C. 1994. Factors affecting pellet quality. Maryland Nutr. Conf. Dept. of Poultry Science and Animal Science, College of Agriculture, University of Maryland, College Park.

Behnke, K. C. 1996. Feed manufacturing technology: Current issues and challenges. Anim. Feed Sci. Technol. 62:49-57.

Behnke, K. C. 2001. Factors influencing pellet quality. FeedTech. Volume 5 Number 4. Reed Business Information, International Agri-\&Horticulture, Doetinchem, The Netherlands.

Briggs, J. L., D. E. Maier, B. A. Watkins, and K. C. Behnke. 1999. Effect of ingredients and processing parameters on pellet quality. Poult. Sci. 78:1464-1471.

Buchanan, N. P., K. G. S. Lilly, C. K. Gehring, and J. S. Moritz. 2010 The effects of altering diet formulation and manufacturing technique on pellet quality. J. Appl. Poult. Res. $19: 112$ 120.

Cannon, D.J., and P. F. Davison. 1978. The crosslinking of skin collagen in annual fish. Exp. Gerontol. 13:101 - 106.

Cutlip, S. E., J. M. Hott, N. P. Buchanan, A. L. Rack, J. D. Latshaw, and J. S. Moritz. The effect of steam-conditioning practices on pellet quality and growing broiler nutritional value. $\mathrm{J}$ Appl Poult Res Summer 2008 17:249-261

Dale, N. 1992. Pelleting effects on lysine bioavailability in diets containing dried bakery product. J Appl Poult Res 1:84-87. 
Dills, W. L. Jr, 1993. Protein fructosylation: fructose and the Maillard reaction. Am. J. Clin. Nutr. 58(suppl):779S-783S.

Fayle, S. E., and J. A. Gerrard. 2002. What is the Maillard reaction? The Maillard Reaction. P. S. Belton, ed. pp. 1-8. The Royal Society of Chemistry., Cambridge, England.

Ford, J. E., and C. Shorrock. 1971. Metabolism of heat-damaged proteins in the rat: Influence of heat damage on the excretion of amino acids and peptides in the urine. Br. J. Nutr. 26:311-322.

Gehring, C. K. Improvement of the physical and nutritional quality of pelleted feed. MS thesis West Virginia University, Morgantown, 2009. Dissertations and Theses. Web. 22 Nov. 2010.

Gehring, C. K., K. G. S. Lilly, L. K. Shires, K. R. Beaman, S. A. Loop, and J. S. Moritz. Increasing mixer-added fat reduces the electrical energy required for pelleting and improves exogenous enzyme efficacy for broilers. J Appl Poult Res 2011 20:75-89.

Hodge, J. E. 1953. Dehydrated foods: Chemistry of browning reactions in model systems. J. Agric. Food Chem. 1:928-943.

Hurrell, R. F., and K. J. Carpenter. 1981. The estimation of available lysine in foodstuffs after Maillard reactions. Prog. Food Nutr. Sci. 5:159-176.

Hussar, N., and A. R. Robblee, 1962. Effects of pelleting on the utilization of feed by the growing chicken. Poultry Sci. 41:1489-1493.

Iqbal, M., L. L. Probert, N. H. Al-humadi, and H. Klandorf. 1999. Protein glycosylation and advanced glycosylation end products (AGEs): an avian solution. J. Gerontol. Biol. Sci. 54: B171-B176.

Jones, F. T., K. E. Anderson, and P. R. Ferket. 1995. Effect of extrusion on feed characteristics and broiler chicken performance. J. Appl. Poult. Res. 4:300-309.

Lilly, K. G. S., C. K. Gehring, K. R. Beaman , P. J. Turk, M. Sperow, and J. S. Moritz. 2011. Examining the relationships between pellet quality, broiler performance, and bird sex. J. Appl. Poult. Res. 20:231-239.

Lilly, K. G. S., L. K. Shires, B. N. Swiger, A. M. Evans, K. J. Shipe, and J. S. Moritz. Resolving pellet quality issues and improving turkey poult performance with the manufacture of commercial turkey diet formulations. West Virginia University. 2011 Poultry Science Association \& American Association of Avian Pathologists Joint Meeting ,Indianapolis, IN. 19 July 2011. Abstract. 
Loop, S. A. Phosphorus nutrition in broilers. MS thesis. West Virginia University, Morgantown, 2009. Dissertations and Theses. Web. 15 May 2012.

Martins, S. I. F. S., W. M. F. Jongen, and M. A. J. S. van Boekel. 2001. A review of Maillard reaction in food and implications to kinetic modeling. Trends Food. Sci. Tech. 11:364373.

Mauron, J. 1981. The Maillard reaction in food: A critical review from the nutritional standpoint. Prog. Food Sci. 5:5-35.

Moritz, J.S. and Lilly K.G.S., 2010. Production strategies and feeding opportunities for pellets of high quality. Proceedings of the 8th 1519 Annual Mid-Atlantic Nutrition Conference, University of Maryland, College Park, MD. pp: 85-90.

Medel, P., M. A. Latorre, C. de Blas, R. Lazaro, and G. G. Mateos. 2003. Heat processing of cereals in mash or pellet diets for young pigs. Anim. Feed Sci. and Tech. 113:127-140.

Panigrahy, G.K., and B. K. Patnaik. 1976. Change in the stability of tendon collagen during ageing in the reptile Calotes ersicolor: a brief note. Mech. Ageing Dev. 5:443 - 446.

Parsons, C.M., K. Hashimoto, K. J. Wedekond, Y. Han, and D. H. Baker. 1992. Effect of overprocessing of availability of amino acids and energy in soybean meal. Poult. Sci. 71:133-140.

Reimer, L. 1992. Conditioning. Proc. Northern Crops Institute Feed Mill Management and Feed Manufacturing Technol. Short Course. p. 7. California Pellet Mill Co. Crawfordsville, IN.

Smith, A., and S. Circle. 1972. Soybeans: Chemistry and technology. Vol. 1. Proteins. The AVI Publishing Co., Westport, CT.

Thomas, M., D. J. van Zuilichem, and A. F. B. Van der Poel. 1997. Physical quality of pelleted animal feed. 2. Contribution of processes and its conditions. Anim. Feed Sci. Tech. 64:173-192.

Valle-Riestra, J., and R. H. Barnes. 1970. Digestion of heat-damaged egg albumen by the rat. J. Nutr. 100:873-882.

Wondra, K. J., J. D. Hancock, K. C. Behnke, and C. R. Stark. 1995. Effects of mill type and particle size uniformity on growth performance, nutrient digestibility, and stomach morphology in finishing pigs. J. Anim. Sci. 73:2564-2573.

Zhang, Y., and C. M. Parsons, 1994. Effects of overprocessing on the nutritional quality of sunflower meal. Poultry Sci.73:436-442. 


\title{
Chapter 2: Effects of Pellet Die Heat and Pressure on Pellet Quality and Broiler Lysine Utilization
}

\author{
K. J. Shipe, A. M. Evans, K. G. S. Wamsley, B. N. Swiger, L. K. Shires, \\ K. P. Blemings, and J.S. Moritz ${ }^{1}$
}

Division of Animal and Nutritional Sciences

West Virginia University, Morgantown 26506

Keywords: lysine, feed manufacture, pellet quality, true amino acid digestibility, furfural, Maillard reaction

Primary Audience: feed manufacturers, broiler producers, nutritionists, researchers

${ }^{1}$ Corresponding Author: Joe.Moritz@mail.wvu.edu 


\section{SUMMARY}

Feed production rate, pellet die specification, and level of mixer-added fat (MAF) influence feed exposure to pellet die frictional heat and pressure that may alter chemical structure of ingredients. Lysine has been indicated as a nutrient with potential to be structurally altered, especially in the presence of heat and reducing sugars, as in Maillard reactions, that may decrease lysine availability. A practical diet containing $7.5 \%$ bakery by-product meal and $0.13 \%$ lysine $\mathrm{HCl}$ was formulated to $90 \%$ of Cobb-Vantress lysine recommendations (i.e. $0.95 \%$ total lysine) to best demonstrate lysine availability differences when manufactured and fed in a factorial experiment that varied production rate, die thickness, and MAF level. Two additional treatments: unprocessed mash and double pelleted were also manufactured and fed. All diets, excluding mash, were steam conditioned at $82^{\circ} \mathrm{C}$ and ground prior to feeding. Pellet mill electrical energy usage, pellet quality, and bulk density were increased with 0.5 tonne/hr production rate, $44.5 \mathrm{~mm}$ pellet die, and $0.5 \% \mathrm{MAF}$ as compared to 0.8 tonne/hr production rate, $38.1 \mathrm{~mm}$ pellet die and 3\% MAF $(\mathrm{P}=0.0001)$, indicating greater feed exposure to pellet die frictional heat and pressure. Bird performance and carcass characteristics were not affected by main effects $(\mathrm{P}>0.05)$; however, contrasts demonstrated that mash fed birds had decreased FCR compared with double pelleted fed birds, with birds fed diets from the factorial treatments being intermediate $(\mathrm{P}<0.05)$. To determine if the mechanism of action responsible for the FCR effects included lysine availability, diets were analyzed for furfural, an intermediate of the Maillard reaction pathway, and assessed for true amino acid digestibility using cecectomized roosters. Furfural concentration was not altered due to processing treatment $(\mathrm{P}>0.05)$. In addition, no differences in lysine digestibility or the digestibility of any other tested amino acid were apparent $(\mathrm{P}>0.05)$. Therefore lysine availability as assessed with this study's specific methodology does not appear to be decreased due to pelleting. 


\section{DESCRIPTION OF THE PROBLEM}

Pelleting feed requires significant time and energy that can result in animal performance benefits that justify the cost of production if feed form integrity is maintained without detriment to nutritional quality (Behnke, 1996; Moritz and Lilly, 2011). Protein is heat sensitive and can change its physical structure in the presence of moist heat. This physical alteration may result in a considerable change in reactivity, functionality, and nutritional quality. Protein denaturation, as defined by Camire et al. (1990), is any changes in conformation of a protein that does not involve breaking peptide bonds. Most proteins unfold and aggregate in the presence of moist heat. The unfolding of protein is reversible if thermal and/or mechanical forces are stopped before aggregation; however, if more heat or shear is added, the non-covalent interactions of the three-dimensional structure will be broken resulting in irreversible protein denaturation (Voragen et al., 1995). Specific factors of influence include temperature, moisture content, shear forces, residence time, $\mathrm{pH}$, lipids, and carbohydrates, with moisture content and shear forces being the primary factors (Voragen et al., 1995). Pelleting which combines shear forces, heat, residence time, and water may result in partial protein denaturation (Thomas et al., 1998) and may result in changes in protein availability to a non-ruminant animal (Voragen et al., 1995).

Pelleting steam conditioned feed may result in the Maillard reaction, where many feed constituents may participate (Thomas et al., 1998). The high temperatures and low moisture used in pellet formation favor the Maillard reaction (Voragen et al., 1995). In the presence of heat and moisture, free aldehyde groups (e.g. glucose) and free amine groups (e.g. epsilon-amino group of lysine) yield melanoides that darken feed and increase digesta viscosity (Voragen et al., 1995; Thomas et al., 1998). This reaction, also known as non-enzymatic browning, has important nutritional and functional significance (Camire et al., 1990). Maillard products may cause nutritional detriment via reduced utilization of proteins and carbohydrates (Pickford, 1992; 
Hendriks et al., 1994; Thomas et al., 1998). Since lysine is limiting in cereal grains and consequently many practically formulated least-cost poultry diets, loss of lysine can be particularly detrimental to live performance. Starch and non-reducing sugars could be hydrolyzed during processing and extrusion, whereby reducing sugars react with lysine, resulting in lysine loss (Camire et al., 1990). High processing temperature has been associated with the degradation of cysteine, the most heat-labile amino acid, followed by lysine, then arginine, threonine, and serine (Papadopoulos, 1989). However, standard feed manufacture conditions and/or diet formulations do not exist and as such, past literature has utilized a variety of conditions without consistent results on bird performance or nutrient availability. Furthermore, feed form benefits may compensate for decreased nutrient availability. Therefore, understanding the effects of feed manufacture on lysine digestibility based on past research is difficult.

Hussar and Robblee (1962) demonstrated no effect on total lysine or available lysine when wheat, oats, and barley were conditioned below $72^{\circ} \mathrm{C}$. Similarly, Dale (1992) attempted to initiate a Maillard reaction in pelleted feed and found that lysine availability was not affected by the pelleting process. The author's description of the pelleting process only included that the diets were manufactured using commercial-type equipment and conditioning temperatures between 85 and $88^{\circ} \mathrm{C}$.

Plavnik et al. (1997) reported that pelleted feed only improved broiler LWG and FCR when pellets remained intact since ground pellets did not improve performance. Bayley et al. (1968) reported no benefits to pelleting feed. Lilly et al. (2011) were successful in creating five different feed form treatments ranging from 71 to $96 \%$ pellet durability index (PDI), yet expected broiler performance differences were not observed. The authors speculated that changes in nutrient availability due to the pelleting process may have been responsible for lack 
of performance differences. Similarly, Buchanan et al. (2010) did not observe expected performance differences when comparing broilers consuming high quality pellets and those consuming low quality pellets. The authors speculated that some form of nutrient detriment had occurred.

The objective of the current study was to identify feed manufacture techniques that alter lysine availability as indicated by broiler performance in the finishing phase, diet furfural content, and true amino acid digestibility. The feed manufacture techniques were narrowed to those associated with feed exposure to frictional heat and pressure within the pellet die.

\section{MATERIALS AND METHODS}

\section{Feed Manufacture}

All diets were formulated to meet or exceed Cobb Vantress (2010) nutrient recommendations, except for lysine content (Table 1). Dietary total lysine was restricted to $90 \%$ of Cobb Vantress recommendations for the starter and grower phases as to not create too high of a plane of nutrition prior to birds being fed experimental diets. All finishing phase diets were formulated to be isocaloric and isonitrogeneous, containing either 80 or $90 \%$ of Cobb Vantress total lysine recommendations to best demonstrate lysine digestibility differences when manufactured and fed. Diets contained $7.5 \%$ bakery by-product meal and $0.13 \%$ lysine HCL. A $2 \times 2 \times 2$ factorial design was conducted with $90 \%$ total lysine diets that evaluated the effects of production rate $(0.5$ or 0.8 tonne/hr), die thickness $(38.1$ or $44.5 \mathrm{~mm})$, and MAF level ( 0.5 or $3 \%$ ) on feed manufacture, broiler performance, and processing yield. Three additional treatments: unprocessed mash, double pelleted (exposed twice to 0.5 tonne/hr production using a 44.5mm die after $0.5 \% \mathrm{MAF}$ ), and an $80 \%$ total lysine diet ( 0.5 tonne/hr production using a 38.1 $\mathrm{mm}$ die and 3\% MAF) were also manufactured and fed. All diets, excluding mash, were steam 
conditioned at $82^{\circ} \mathrm{C}$ and ground prior to feeding. Feed manufacture occurred at the West Virginia University pilot feed mill.

Finisher feed was manufactured using $204 \mathrm{~kg}$ batches in a randomized complete block design. The blocking factor was day of manufacture and pelleting was conducted over four replicate days. Batches were mixed using a single-screw vertical mixer (Weigh-Tronix). Feed was batched at two mixer-added fat (MAF) levels: 0.5 or $3 \%$ of the diet. Treatments that incorporated $0.5 \%$ MAF had the remaining 2.5\% fat added post pelleting. Feed was conditioned at $82^{\circ} \mathrm{C}$ using a short-term conditioner (CPM) with a $10 \mathrm{~s}$ retention time. Pellets were formed using a CPM mill (Master Model), fitted with either a $30.48 \mathrm{~cm}$ (12 in), $4.76 \mathrm{~mm}$ (3/16 in) x 38.1 $\mathrm{mm}$ (1.5 in) die or a $30.48 \mathrm{~cm}(12 \mathrm{in}), 4.76 \mathrm{~mm}$ (3/16 in) x $44.5 \mathrm{~mm}$ (1.75 in) die. Pellets were cooled using a horizontal belt cooler (Pyramid Processing Equipment, LLC). Feed fines were not recirculated back to the pellet mill. Prior to pelleting experimental feed, the die was warmed up with approximately $136 \mathrm{~kg}$ of feed. The first bag of each batch was discarded to avoid crossbatch contamination.

Relative electrical energy usage of the conditioner (CREEU) and pellet mill (PREEU), were recorded (Powerlogic meters) and production rate was calculated based on the time of each run and volume of feed produced. Bulk density and pellet durability were determined using samples of cool pellets (pellets sampled immediately after exiting the cooler). Both fines generated at the cooler and bagged samples of cool pellets were utilized in the determination of percent fines. Tests to determine pellet structural integrity i.e. PDI and modified pellet durability index (MPDI) were calculated for all pertinent treatments (ASAE S269.4).

Feed manufacture data was analyzed as a randomized complete block using one-way ANOVA while considering main effects and interactions. Significance was determined at $\mathrm{P} \leq$ 
0.05. Multiple comparisons of all treatment means were made using Fisher's LSD. Main effects and interactions of factorial treatments were also determined. The statistical analyses were conducted using the GLM procedure of SAS, (2011).

\section{Broiler Performance}

Two-thousand one hundred twelve feather-sexed male Cobb 500 broiler chicks obtained from a commercial hatchery (Matterns Hatchery Inc.) were housed in a solid-sided negative pressure research facility heated with thermostatically controlled forced air heaters. Each pen contained approximately 25 birds during the starter and grower periods, one hanging feeder (Kuhl feed pan), one drinker line with three nipples (Ziggity), and built-up litter. Brooding temperature was $33^{\circ} \mathrm{C}$ and was decreased by $3^{\circ} \mathrm{C}$ per week until a final set point of $21^{\circ} \mathrm{C}$ was reached. Temperature was adjusted according to broilers' thermal neutral zone as assessed by visual inspection. Lighting was as follows: continuous light from d 1-3, 23L:1D from d 4-7, 20L:4D from d 8-24, and 23L:1D for the remainder of the study. Birds were provided ad libitum feed and water. Pelleted diets were ground via a roller mill to eliminate feed-form effects associated with feeding pellets.

On d 23 birds were reorganized so that all pens contained 22 birds and did not differ in 23 day pen weight (Table 3) and experimental diets were fed. On d 42, broilers were weighed and feed consumption was measured. Live weight gain (LWG), feed intake (FI), FCR (adjusted for mortality), and percent mortality were calculated for the 23 to $42 \mathrm{~d}$ finisher period (Table 3 ). Mortalities were collected and recorded daily. On d 42, five birds from each pen were selected at random for processing. Thus, approximately $25 \%$ of each experimental unit was processed and used to determine carcass variables. Selected birds were weighed, euthanized, and deboned 
manually to separate the pectoralis major and minor muscles (Table 3 ). Total breast and percent breast relative to bird weight were calculated (Table 3 ).

Broiler performance data was analyzed as a randomized complete block design using one-way ANOVA while considering main effects and interactions. The experimental unit was a pen of 22 male broilers. Significance was determined at $\mathrm{P} \leq 0.05$. Multiple comparisons of means were made using Fisher's LSD. The statistical analyses were conducted using the GLM procedure of SAS (2011). Post hoc contrasts were utilized when comparing birds consuming feed from the factorial treatments to those consuming either the mash or double pelleted treatments.

\section{Furfural Analysis}

Two pounds of feed from each day of manufacture was randomly sampled from each treatment and stored below $0^{\circ} \mathrm{C}$ until analysis. The determination of furfural was based on the methods of García-Villanova et. al (1993) and Rufián-Henares et. al (2006) with minor modifications. Ground feed samples $(500 \mathrm{mg})$ were suspended in $5 \mathrm{~mL}$ of deionized water in a $10 \mathrm{~mL}$ centrifuge tube. The tube was shaken vigorously for one minute and clarified with 0.25 $\mathrm{mL}$ of potassium ferrocyanide $(15 \% \mathrm{w} / \mathrm{v})$ and $0.25 \mathrm{~mL}$ zinc acetate $(30 \% \mathrm{w} / \mathrm{v})$ solutions. The resulting mixture was centrifuged at $4,500 \mathrm{~g}$ for 10 minutes at $4{ }^{\circ} \mathrm{C}$. The supernatant was collected in a $10 \mathrm{~mL}$ volumetric flask. Two further extractions were performed using $2 \mathrm{~mL}$ of deionized water. Supernatants were mixed; when the volumes were less than $10 \mathrm{~mL}$, deionized water was used to bring the total volume to $10 \mathrm{~mL}$. Analyses for furfural were performed on the filtered $(0.45 \mu \mathrm{m})$ solution using Waters HPLC.

The HPLC system consisted of a Waters 1525 binary pump, a Waters 717 Plus auto sampler, Waters 2487 dual wavelength absorbance detector, and a Waters bus Sat/In module. 
The mobile phase was a mixture of $21.76 \mathrm{~g}$ sodium acetate ( $\mathrm{pH} 3.6)$ per liter of water delivered at a flow rate of $1 \mathrm{~mL}$ per minute under isocratic conditions through the analytical column (YMC ODS-AQ $5 \mu \mathrm{m} 120 \mathrm{~A}$ ), thermostated at $32^{\circ} \mathrm{C}$. The injection volume was $20 \mu \mathrm{L}$ and detection was via a UV detector, which was set a $280 \mathrm{~nm}$. Furfural was quantified using a standard curve ranging from 0.02 to 15.0 picomoles.

HPLC data was analyzed as a randomized complete block design using one-way ANOVA while considering main effects and interactions. Significance was determined by $\mathrm{P} \leq$ 0.05. The statistical analyses were conducted using the GLM procedure of SAS (2011).

\section{True Amino Acid Digestibility}

Forty 38 week old cecectomized Single Comb White Leghorns were utilized to determine true amino acid digestibility of four treatments that were previously fed to finishing broilers, which included unconditioned mash, double pelleted, feed pelleted using 0.8 tonne/h production rate, a $38.1 \mathrm{~mm}$ die, and 3\% MAF, and feed pelleted using a 0.5 tonne/h production rate, a 44.5mm die, and 0.5\% MAF. Eight roosters per treatment were precision fed following modified methodologies of Sibbald (1976) with an additional 8 roosters being precision fed corn starch pellets as a means for endogenous correction. Collected excreta were dried at $50^{\circ} \mathrm{C}$ for $24 \mathrm{~h}$ before amino acid analysis to determine true digestibility of lysine, leucine, isoleucine, methionine, valine, cysteine, alanine, glycine, proline, glutamine, threonine, and aspartate.

True digestibility of the tested amino acids was analyzed as a completely randomized block design using one-way ANOVA while considering main effects and interactions.

Significance was determined by $\mathrm{P} \leq 0.05$. The statistical analyses were conducted using the GLM procedure of SAS (2011). 


\section{RESULTS AND DICSUSSION}

\section{Feed Manufacture}

Feed produced at 0.5 tonne/hr had higher PDI and MPDI than feed produced at 0.8 tonne $/ \mathrm{hr}(\mathrm{P}<0.0001$; Table 2). Feed produced using a $44.5 \mathrm{~mm}$ thick die had higher PDI and MPDI than feed produced using a $38.1 \mathrm{~mm}$ thin die $(\mathrm{P}=0.0001)$. Feed produced with $0.5 \%$ MAF had higher PDI and MPDI than feed produced with 3\% MAF ( $<<0.0001)$. The MPDI metric estimates pellet durability at the feed pan after stressors of transportation and augering. Energy usage of the pellet mill and bulk density of feed increased with slow production rate, thick die use, and low mixer-added fat $(\mathrm{P}<0.0001)$. These data indicate that the manufacture main effects were successful in creating greater die frictional heat and pressure that resulted in increased pellet binding reactions. Past research has shown that increasing frictional heat and pressure can increase starch gelatinization and protein denaturation (Moritz et al., 2005; Cramer et al., 2003). In addition, these conditions have also been speculated to be detrimental to nutrient availability (Buchanan et al., 2010; Lilly et al., 2011; Gehring et al., 2011).

Particle size analysis was conducted (ASAE S319.2). Median size is measured in Dgw, which is defined as the particle diameter at $50 \%$ probability of a size distribution curve, equivalent to geometric mean diameter. Sgw is defined as the log-normal standard deviation. The particle size of ground pellets ranged from $582 \mathrm{Dgw} \pm 1.98 \mathrm{Sgw}$ to $714 \mathrm{Dgw} \pm 2.21 \mathrm{Sgw}$ with a mean of $628 \mathrm{Dgw} \pm 2.08 \mathrm{Sgw}$, while the particle size of mash was $747 \mathrm{Dgw} \pm 2.18 \mathrm{Sgw}$. These small differences were likely not great enough to cause changes in feed retention time in the gastrointestinal tract that could potentially affect broiler performance as reported previously (Parsons et al., 2006; Jacobs et al., 2010). 


\section{Broiler Performance}

No differences in performance $(\mathrm{P}>0.05$; Table 3$)$ were observed among treatments in the factorial structure. Contrasts demonstrated that birds fed mash had lower FCR compared with birds fed double pelleted feed, with birds fed diets from the factorial treatments being intermediate $(\mathrm{P}<0.05)$. These data suggest that pelleting in general had deleterious effects on nutrient availability that could not be identified by varying feed exposure in the die. At this point, it was unclear whether or not lysine or other nutrients were affected.

No differences in processing yield ( $\mathrm{P}>0.05$; Table4) were observed among treatments in the factorial structure. Birds consuming ground pellets that had been formulated to meet $80 \%$ of the lysine recommendation by Cobb-Vantress, as compared to all other treatments which were formulated to $90 \%$ of the same lysine recommendation, had less pectoralis major $(\mathrm{P}<0.01)$, less total breast weight $(\mathrm{P}<0.01)$, and lower breast yield $(\mathrm{P}<0.0001)$. Perhaps, even at $90 \%$ of the breeder recommendation for lysine, diets were not marginal enough to elicit responses.

Plavnik et al. (1997) reported that bird performance associated with the consumption of ground pellets that had been steam conditioned was either not different or inferior to that of birds consuming mash and that the results did not point to an improvement in nutrient availability. Past research has speculated that perhaps improvement in nutrient availability due to pelleting is not large enough to affect the overall nutritional value of feed or is offset by possible detrimental effects (Bayley et al., 1968). Suggested possibilities for nutrient detriment have been described as vitamin decomposition, fat oxidation, and amino acid destruction (Moran and Summers, 1970). Perhaps, even at $90 \%$ of the recommendation for lysine by Cobb-Vantress diets may not have been marginal enough in lysine to elicit responses. 


\section{Furfural Analysis}

Furfural content is show in table 5. The analysis was completed in 20 minutes with furfural peaking at 9.7 minutes. Furfural concentration was not altered due to processing treatment $(\mathrm{P}>0.05)$. Differing pelleting technique, or even the process of pelleting, did not result in different levels of furfural, suggesting that the Maillard reaction did not occur $(\mathrm{P}=0.1497)$ due to the pelleting techniques utilized in this study. It is likely that furfural already existed in the ingredients prior to pelleting, especially with respect to the bakery by-product used.

\section{True Amino Acid Digestibility}

No differences in lysine digestibility or the digestibility of any other tested amino acid were apparent ( $\mathrm{P}>0.05$; Table 6$)$. Therefore, lysine digestibility as assessed with this study's specific methodologies does not appear to be decreased due to pelleting. These findings are in agreement with Dale (1992). Similarities between the current study and Dale's work include a high inclusion of bakery by-product meal that contains a substantial level of crude fat (10 13\%). Perhaps higher fat levels in both studies contributed by bakery by-product meal aided in lubricating the pellet mill die, consequently reducing high frictional heat and pressure, and thus the potential for Maillard reaction. In addition, the current study utilized dried distillers grains and solubles at a level of 5\%. The specific DDGS used in this study had a crude fat content of $10 \%$. This ingredient could also contribute to lubricating effects.

It cannot be dismissed that steam conditioning may create increased digesta viscosity. Digesta viscosity of birds fed wheat-based diets without xylanase increases when feeding pellets as compared to mash, while viscosity with the inclusion of xylanase is similar between pellet and mash fed digesta (Cowieson et al., 2005). This study demonstrated decreased bird performance for birds fed ground pellets, and we attributed the effect to the increase in viscosity due to 
increased solubility of NSPs. This agrees with Samarasinghe et al. (2000) who observed that increasing conditioning temperature increased viscosity $\left(60^{\circ} \mathrm{C}\right.$ as compared to 75 and $\left.90^{\circ} \mathrm{C}\right)$ in barley-soy-corn diets.

Non-starch polysaccharides (NSPs) exhibit several anti-nutritive characteristics (Choct and Annison, 1992). The portion of NSPs that are of high molecular weight solubilizes in the intestines, increasing gut viscosity (Fengler and Marquardt 1988; Choct and Annison 1992) which causes decreased feed passage rate, decreased feed intake, increased water consumption, increased bacterial proliferation in the gastrointestinal tract, and changes in gut microflora (Fengler and Marquardt 1988; Choct and Annison, 1990, 1992; Silversides and Bedford, 1999; Bedford, 2002). Perhaps FCR differences in the current study were in part a result of cell wall carbohydrates in corn and soybean such as xylose being liberated due to thermal processing, thereby increasing digesta viscosity and decreasing overall broiler performance.

\section{CONCLUSIONS AND APPLICATIONS}

1. Lysine availability as assessed with these studies specific methodology was not decreased due to pelleting.

2. The general pelleting process utilized in this study altered diets in a manner that decreased broiler performance. The mechanism or nutrients involved in the alteration are unclear. 


\section{REFERENCES AND NOTES}

Ames, J. M. 1990. Control of the Maillard reaction in food systems. Trends Food Sci. Technol. $1: 150-154$.

American Society of Agricultural Engineers. 1997. ASAE S269.4: Cubes, pellets, and crumblesDefinitions and methods for determining density, durability, and moisture. ASAE Standards 1997. Am. Soc. Agric. Eng., St. Joseph, MI.

American Society of Agricultural Engineers. 1997. ASAE S319.2: Method of determining and expressing fineness of feed materials by seiving. ASAE Standards 1997. Am. Soc. Agric. Eng., St. Joseph, MI.

Anderson-Haferman, J. C., Y. Zhang and C.M. Parsons. 1993. Effects of processing on the nutritional quality of canola meal. Poult. Sci. 72:326-333.

Baird, D. M. 1973. Influence of pelleting swine diets on metabolizable energy, growth and carcass characteristics. J. Anim. Sci. 36:516-521.

Bayley, H. S., J. D. Summers, and S. J. Slinger. 1968. The influence of steam pelleting conditions on the nutritional value of chick diets. Poultry Sci. 47:931-939.

Behnke, K. C. 1994. Factors affecting pellet quality. Maryland Nutr. Conf. Dept. of Poultry Science and Animal Science, College of Agriculture, University of Maryland, College Park.

Behnke, K. C. 1996. Feed manufacturing technology: Current issues and challenges. Anim. Feed Sci. Technol. 62:49-57.

Behnke, K. C. 2001. Factors influencing pellet quality. FeedTech. Volume 5 Number 4. Reed Business Information, International Agri-\&Horticulture, Doetinchem, The Netherlands.

Buchanan, N. P., K. G. S. Lilly, and J. S. Moritz. 2010. The effects of diet formulation, manufacturing technique, and antibiotic inclusion on broiler performance and intestinal morphology. J. Appl. Poult. Res. 19:121-131.

Cannon, D.J., and P. F. Davison. 1978. The crosslinking of skin collagen in annual fish. Exp. Gerontol. 13:101 - 106.

Cobb 500 broiler performance and nutrition supplement, Cobb-Vantress Inc., Siloam Springs, AR.

Cramer, K. R., K. J. Wilson, J. S. Moritz, and R. S. Beyer. 2003. Effect of Sorghum-based diets subjected to various manufacturing procedures on broiler performance. J. Appl. Poult. Res. 12:404-410. 
Cutlip, S. E., J. M. Hott, N. P. Buchanan, A. L. Rack, J. D. Latshaw, and J. S. Moritz. 2008. The effect of steam-conditioning practices on pellet quality and growing broiler nutritional value. J. Appl. Poult. Res. 17:249-261.

Dills, W. L. Jr, 1993. Protein fructosylation: fructose and the Maillard reaction. Am. J. Clin. Nutr. 58(suppl):779S-783S.

Fayle, S. E., and J. A. Gerrard. 2002. What is the Maillard reaction? The Maillard Reaction. P. S. Belton, ed. pp1-8 The Royal Society of Chemistry., Cambridge, England.

Ford, J. E., and C. Shorrock. 1971. Metabolism of heat-damaged proteins in the rat: Influence of heat damage on the excretion of amino acids and peptides in the urine. Br. J. Nutr. 26:311-322.

Gehring, C. K. Improvement of the physical and nutritional quality of pelleted feed. MS thesis West Virginia University, Morgantown, 2009. Dissertations and Theses. Web. 22 Nov. 2010.

Gehring, C. K., K. G. S. Lilly, L. K. Shires, K. R. Beaman, S. A. Loop, and J. S. Moritz. 2011. Increasing mixer-added fat reduces the electrical energy required for pelleting and improves exogenous enzyme efficacy for broilers. J. Appl. Poult. Res. 20: 75-89.

Hodge, J. E. 1953. Dehydrated foods: Chemistry of browning reactions in model systems. J. Agric. Food Chem. 1:928-943.

Hurrell, R. F., and K. J. Carpenter. 1981. The estimation of available lysine in foodstuffs after Maillard reactions. Prog. Food Nutr. Sci. 5:159-176.

Hussar, N., and A. R. Robblee, 1962. Effects of pelleting on the utilization of feed by the growing chicken. Poultry Sci. 41:1489-1493.

Iqbal, M., L. L. Probert, N. H. Al-humadi, and H. Klandorf. 1999. Protein glycosylation and advanced glycosylation end products (AGEs): an avian solution. J. Gerontol. Biol. Sci. 54: B171-B176.

Jacobs, C. M., P. L. Utterback, and C. M. Parsons. 2010. Effects of corn particle size on growth performance and nutrient utilization in young chicks. Poult. Sci. 89:539-544.

Kuhl Corporation, Flemington, New Jersey.

Lilly, K. G. S., C. K. Gehring, K. R. Beaman , P. J. Turk, M. Sperow, and J. S. Moritz. 2011. Examining the relationships between pellet quality, broiler performance, and bird sex. J. Appl. Poult. Res. 20:231-239. 
Martins, S. I. F. S., W. M. F. Jongen, M. A. J. S. van Boekel. 2001. A review of Maillard reaction in food and implications to kinetic modeling. Trends Food. Sci. Tech. 11:364373.

Mattern's Hatchery Inc., Beaver Springs, PA.

Mauron, J. 1981. The Maillard reaction in food: a critical review from the nutritional standpoint. Prog. Food Sci. 5:5-35.

Medel, P., M. A. Latorre, C. de Blas, R. Lazaro, and G. G. Mateos. 2003. Heat processing of cereals in mash or pellet diets for young pigs. Anim. Feed Sci. and Tech. 113:127-140.

Moran, E. E. and J. D. Summers. 1970. Factors in feed processing affecting utilization of nutrients. Feedstuffs 42:(October 31)26-27.

Moritz, J. S., A. S. Parsons, N. P. Buchanan, W. B. Calvalcanti, K. R. Cramer, and R. S. Beyer. 2005. Effect of gelatinizing dietary starch through feed processing on zero- to threeweek broiler performance and metabolism. J. Appl. Poult. Res. 14:47-54.

Moritz, J.S., Lilly K.G.S., 2010. Production strategies and feeding opportunities for pellets of high quality. Proceedings of the 8th 1519 Annual Mid-Atlantic Nutrition Conference, University of Maryland, College Park, MD. pp: 85-90.

Panigrahy, G.K., and B. K. Patnaik. 1976. Change in the stability of tendon collagen during ageing in the reptile Calotes ersicolor : a brief note. Mech. Ageing Dev. 5:443 - 446.

Parsons, C.M., K. Hashimoto, K. J. Wedekond, Y. Han, D. H. Baker. 1992. Effect of overprocessing of availability of amino acids and energy in soybean meal. Poult. Sci. 71:133-140.

Parsons, A. S., N. P. Buchanan, K. P. Blemings, M. E. Wilson, and J. S. Moritz. 2006. Effect of corn particle size and pellet texture on broiler performance in the growing phase. J. Appl. Poult. Res. 15:245-255.

Powerlogic power meters attached to the 3-phase leads of the pellet mill main drive and conditioner motor (Square D, Palatine, IL).

Pyramid Processing Equipment, LLC, Stilwell, KS.

Reimer, L. 1992. Conditioning. In: Proc. Northern Crops Institute Feed Mill Management and Feed Manufacturing Technol. Short Course. p. 7. California Pellet Mill Co. Crawfordsville, IN.

SAS Institute. 2011. The SAS System for Windows 2007. SAS Inst. Inc., Cary, NC 
Sibbald, I. R. 1976. A bioassay for true metabolizable energy in feedingstuffs. Poult. Sci. 55:303-308.

Thomas, M., D. J. van Zuilichem, and A. F. B. Van der Poel. 1997. Physical quality of pelleted animal feed. 2. Contribution of processes and its conditions. Anim. Feed Sci. Tech. 64:173-192.

Valle-Riestra, J., and R. H. Barnes. 1970. Digestion of heat-damaged egg albumen by the rat. J. Nutr. 100:873-882.

Wondra, K. J., J. D. Hancock, K. C. Behnke, and C. R. Stark. 1995. Effects of mill type and particle size uniformity on growth performance, nutrient digestibility, and stomach morphology in finishing pigs. J. Anim. Sci. 73:2564-2573.

WVU Pilot Feed Mill: Weigh-Tronix SFM-2000 stationary feed mill (hammer mill, scale, micro ingredient mixer); 15 -horse power hammer mill; one ton capacity single-screw vertical mixer; California Pellet Mill short term conditioner (3 steam inlet ports), $429 \mathrm{rpm}$ shaft speed; 21 picks; 10-s feed retention time; California Pellet Mill master model pellet mill; 40-HP main drive motor

Zhang, Y., and C. M. Parsons, 1994. Effects of overprocessing on the nutritional quality of sunflower meal. Poultry Sci.73:436-442.

Ziggity Systems, Inc., Middlebury, Indiana. 
Table 1. 23-42d broiler finisher diet formulation

\begin{tabular}{|c|c|c|}
\hline \multirow{2}{*}{ Ingredient } & \multicolumn{2}{|c|}{ Inclusion (\%) } \\
\hline & $80 \%$ Lysine & $90 \%$ Lysine \\
\hline Corn & 59.42 & 59.39 \\
\hline Soybean Meal & 18.70 & 18.74 \\
\hline Bakery Product ${ }^{1}$ & 7.50 & 7.50 \\
\hline DDGS, corn & 5.00 & 5.00 \\
\hline Fat, Soybean Oil & 3.00 & 3.00 \\
\hline Porcine Meat \& Bone Meal & 3.00 & 3.00 \\
\hline Limestone & 1.01 & 1.01 \\
\hline Defl. Phosphorus & 0.99 & 0.99 \\
\hline Sand & 0.67 & 0.53 \\
\hline HCl-Lysine & 0.00 & 0.13 \\
\hline DL-Methionine & 0.26 & 0.26 \\
\hline Poultry Pre-mix & 0.25 & 0.25 \\
\hline Threonine & 0.12 & 0.12 \\
\hline Coban 90 & 0.05 & 0.05 \\
\hline BMD $60^{2}$ & 0.04 & 0.04 \\
\hline \multicolumn{3}{|c|}{ Calculated Values } \\
\hline $\mathrm{ME}(\mathrm{kcal} / \mathrm{kg})$ & 3183 & 3183 \\
\hline Crude Protein (\%) & 18.08 & 18.14 \\
\hline Total Lysine (\%) & 0.85 & 0.95 \\
\hline TSAA $(\%)^{3}$ & 0.82 & 0.82 \\
\hline \multicolumn{3}{|c|}{ Analyzed Values } \\
\hline Crude Protein $(\%)$ & 17.59 & 17.85 \\
\hline Total Lysine (\%) & 0.85 & 0.96 \\
\hline Available Lysine (\%) & 0.78 & 0.89 \\
\hline
\end{tabular}

${ }^{1} 90.02 \%$ dry matter, $7.0 \%$ min. crude fat, $14.32 \%$ water soluble carbohydrates (sucrose, fructose, glucose, and lactose), $45.79 \%$ starch, 1.98 nanomoles/g furfural

${ }^{2}$ Bacitracin methylene disalicylate

${ }^{3}$ Total sulfur amino acids 
Table 2. 23-42d broiler finisher feed manufacture variables

\begin{tabular}{|c|c|c|c|c|c|c|c|}
\hline Treatment & $\begin{array}{l}\text { PDI } \\
(\%)\end{array}$ & $\begin{array}{l}\text { MPDI } \\
(\%)\end{array}$ & $\begin{array}{c}\text { Total } \\
\text { Fines } \\
(\%) \\
\end{array}$ & $\begin{array}{c}\text { Bulk } \\
\text { Density } \\
\left(\mathrm{kg} / \mathrm{m}^{3}\right)\end{array}$ & $\begin{array}{c}\text { Production } \\
\text { Rate } \\
\text { (tonne } / \mathrm{h} \text { ) } \\
\end{array}$ & $\begin{array}{c}\text { PREEU } \\
(\mathrm{kWh} / \text { tonne })\end{array}$ & $\begin{array}{c}\text { CREEU } \\
\text { (kWh/tonne) }\end{array}$ \\
\hline Fast, $44.5 \mathrm{~mm}, 0.5 \% \mathrm{MAF}^{1}$ & $94.55^{\mathrm{c}, \mathrm{d}}$ & $92.65^{\mathrm{c}}$ & $9.77^{\mathrm{e}}$ & $656.40^{\mathrm{a}, \mathrm{b}, \mathrm{c}}$ & $0.80^{\mathrm{b}, \mathrm{c}}$ & $8.10^{\mathrm{d}}$ & $0.76^{\mathrm{c}}$ \\
\hline Fast, $44.5 \mathrm{~mm}, 3 \% \mathrm{MAF}^{1}$ & $89.82^{\mathrm{f}}$ & $84.74^{\mathrm{e}}$ & $14.78^{\mathrm{a}, \mathrm{b}, \mathrm{c}}$ & $647.55^{\mathrm{b}, \mathrm{c}, \mathrm{d}}$ & $0.80^{\mathrm{b}, \mathrm{c}}$ & $6.63^{\mathrm{e}, \mathrm{f}}$ & $0.82^{\mathrm{c}}$ \\
\hline Fast, $38.1 \mathrm{~mm}, 0.5 \% \mathrm{MAF}^{1}$ & $93.55^{\mathrm{d}}$ & $91.42^{\mathrm{c}}$ & $9.95^{\mathrm{d}, \mathrm{e}}$ & $641.38^{\mathrm{c}, \mathrm{d}}$ & $0.81^{\mathrm{a}, \mathrm{b}, \mathrm{c}}$ & $7.25^{\mathrm{d}, \mathrm{e}}$ & $0.74^{\mathrm{c}}$ \\
\hline Fast, $38.1 \mathrm{~mm}, 3 \% \mathrm{MAF}^{1}$ & $87.13^{\mathrm{g}, \mathrm{h}}$ & $80.74^{\mathrm{f}}$ & $14.17^{\mathrm{b}, \mathrm{c}}$ & $634.89^{\mathrm{d}}$ & $0.79^{\mathrm{c}}$ & $6.18^{\mathrm{f}}$ & $0.80^{\mathrm{c}}$ \\
\hline Slow, $44.5 \mathrm{~mm}, 0.5 \% \mathrm{MAF}^{1}$ & $96.08^{\mathrm{b}}$ & $94.91^{\mathrm{b}}$ & $13.67^{b, c}$ & $671.09^{\mathrm{a}}$ & $0.48^{\mathrm{d}}$ & $10.47^{\mathrm{b}}$ & $1.15^{\mathrm{b}}$ \\
\hline Slow, $44.5 \mathrm{~mm}, 3 \% \mathrm{MAF}^{1}$ & $91.44^{\mathrm{e}}$ & $87.07^{\mathrm{d}}$ & $16.20^{\mathrm{a}, \mathrm{b}}$ & $665.57^{\mathrm{a}, \mathrm{b}}$ & $0.46^{\mathrm{d}}$ & $8.05^{\mathrm{d}}$ & $1.23^{\mathrm{b}}$ \\
\hline Slow, $38.1 \mathrm{~mm}, 0.5 \% \mathrm{MAF}^{1}$ & $95.01^{\mathrm{b}, \mathrm{c}}$ & $93.33^{\mathrm{b}, \mathrm{c}}$ & $13.50^{\mathrm{b}, \mathrm{c}}$ & $657.64^{\mathrm{a}, \mathrm{b}, \mathrm{c}}$ & $0.48^{\mathrm{d}}$ & $9.23^{\mathrm{c}}$ & $1.22^{\mathrm{b}}$ \\
\hline Slow, $38.1 \mathrm{~mm}, 3 \% \mathrm{MAF}^{1}$ & $89.72^{\mathrm{f}}$ & $84.40^{\mathrm{e}}$ & $17.45^{\mathrm{a}}$ & $649.75^{\mathrm{b}, \mathrm{c}, \mathrm{d}}$ & $0.47^{\mathrm{d}}$ & $7.43^{\mathrm{d}, \mathrm{e}}$ & $1.23^{\mathrm{b}}$ \\
\hline $80 \%$ Lysine $^{2}$ & $85.92^{\mathrm{h}}$ & $80.47^{\mathrm{f}}$ & $13.13^{\mathrm{c}}$ & $663.24^{\mathrm{a}, \mathrm{b}}$ & $0.83^{\mathrm{a}}$ & $6.02^{\mathrm{f}}$ & $0.79^{\mathrm{c}}$ \\
\hline Unprocessed Mash $^{1}$ & -- & -- & -- & -- & -- & -- & -- \\
\hline Double Pellet $^{1}$ & $97.71^{a}$ & $97.17^{\mathrm{a}}$ & $13.79^{\mathrm{b}, \mathrm{c}}$ & $675.10^{\mathrm{a}}$ & $0.22^{\mathrm{e}}$ & $24.35^{\mathrm{a}}$ & $2.59^{\mathrm{a}}$ \\
\hline ANOVA P value & $<0.0001$ & $<0.0001$ & 0.0004 & 0.0036 & $<0.0001$ & $<0.0001$ & $<0.0001$ \\
\hline SEM $^{3}$ & 0.4984 & 0.7318 & 1.0459 & 0.4484 & 0.0083 & 0.2935 & 0.0423 \\
\hline Fisher's LSD & 1.4394 & 2.1135 & 3.0208 & 1.295 & 0.0239 & 0.8478 & 0.1222 \\
\hline \multicolumn{8}{|c|}{ Marginal Means } \\
\hline \multicolumn{8}{|l|}{ Production Rate } \\
\hline Slow & 93.06 & 89.93 & 15.20 & 661.01 & 0.47 & 8.79 & 1.21 \\
\hline Fast & 91.26 & 87.32 & 12.16 & 645.05 & 0.80 & 7.04 & 0.78 \\
\hline \multicolumn{8}{|l|}{ Die Thickness } \\
\hline $38.1 \mathrm{~mm}$ & 91.35 & 87.41 & 13.76 & 645.91 & 0.64 & 7.52 & 1.00 \\
\hline $44.5 \mathrm{~mm}$ & 92.97 & 89.84 & 13.60 & 660.15 & 0.64 & 8.31 & 0.99 \\
\hline \multicolumn{8}{|l|}{ MAF } \\
\hline $0.5 \%$ & 94.80 & 93.08 & 11.72 & 656.63 & 0.64 & 8.76 & 0.97 \\
\hline $3 \%$ & 89.53 & 84.17 & 15.65 & 649.44 & 0.63 & 7.07 & 1.02 \\
\hline \multicolumn{8}{|c|}{ Main Effects and Interaction Probabilities } \\
\hline Production Rate & $<0.0001$ & $<0.0001$ & 0.0004 & $<0.0001$ & $<0.0001$ & $<0.0001$ & $<0.0001$ \\
\hline Die Thickness & 0.0001 & $<0.0001$ & 0.8214 & $<0.0001$ & 0.6834 & 0.0003 & 0.7762 \\
\hline MAF & $<0.0001$ & $<0.0001$ & $<0.0001$ & $<0.0001$ & 0.0652 & $<0.0001$ & 0.0514 \\
\hline $\begin{array}{l}\text { Production Rate } \\
\text { x Die Thickness } \\
\end{array}$ & 0.5225 & 0.5304 & 0.6027 & 0.7466 & 0.9679 & 0.4498 & 0.2777 \\
\hline Production Rate $\mathrm{x}$ MAF & 0.3850 & 0.2997 & 0.3479 & 0.6984 & 0.8458 & 0.0315 & 0.8195 \\
\hline Die Thickness x MAF & 0.1026 & 0.0493 & 0.8274 & 1.0000 & 0.6079 & 0.1764 & 0.5624 \\
\hline $\begin{array}{l}\text { Production Rate } \\
\text { x Die Thickness x MAF }\end{array}$ & 0.4559 & 0.3347 & 0.4490 & 0.3451 & 0.1678 & 0.7468 & 0.4341 \\
\hline
\end{tabular}

${ }^{a-h}$ Values within comparisons with different superscripts differ $(\mathrm{P} \leq 0.05)$ 
${ }^{1} 90 \%$ of Cobb's lysine recommendations

${ }^{2} 80 \%$ of Cobb's lysine recommendations; fast production rate, $38.1 \mathrm{~mm}(1.5 \%)$ die, $3 \%$ MAF

${ }^{3}$ Standard Error of the Mean, an estimate of the amount that an obtained mean may be expected to differ by chance from the true mean 
Table 3. 23-42d male broiler chick performance ${ }^{1}$

\begin{tabular}{|c|c|c|c|c|c|c|}
\hline Treatment & $\begin{array}{l}\text { 23d BPW } \\
\pm \text { SD (kg) }\end{array}$ & $\begin{array}{c}\text { EBW } \\
\pm \text { SD }(k g)\end{array}$ & $\begin{array}{l}\text { Mortality } \\
\pm \mathrm{SD}(\%)\end{array}$ & $\begin{array}{c}\text { LWG days } \\
\pm \mathrm{SD}(\mathrm{kg})\end{array}$ & $\begin{array}{c}\text { FI } \\
\pm \mathrm{SD}(\mathrm{kg})\end{array}$ & $\begin{array}{c}\text { FCR } \\
\pm \mathrm{SD}(\mathrm{kg} / \mathrm{kg})\end{array}$ \\
\hline Fast, Thick, Low MAF ${ }^{2}$ & $12.805 \pm 0.424$ & $1.798 \pm 0.102$ & $3.75 \pm 3.54$ & $1.188 \pm 0.114$ & $44.608 \pm 3.597$ & $2.01 \pm 0.06^{\mathrm{c}, \mathrm{d}}$ \\
\hline Fast, Thick, High MAF ${ }^{3}$ & $12.858 \pm 0.628$ & $1.772 \pm 0.168$ & $3.75 \pm 5.18$ & $1.176 \pm 0.196$ & $45.937 \pm 4.337$ & $2.01 \pm 0.05^{\mathrm{c}, \mathrm{d}}$ \\
\hline Fast, Thin, Low MAF ${ }^{4}$ & $13.029 \pm 0.246$ & $1.783 \pm 0.177$ & $2.53 \pm 2.71$ & $1.148 \pm 0.187$ & $43.781 \pm 5.101$ & $2.02 \pm 0.11^{\mathrm{c}}$ \\
\hline Fast, Thin, High MAF & $12.913 \pm 0.620$ & $1.751 \pm 0.077$ & $1.91 \pm 2.63$ & $1.113 \pm 0.080$ & $43.664 \pm 2.614$ & $2.04 \pm 0.06^{\mathrm{b}, \mathrm{c}}$ \\
\hline Slow, Thick, Low MAF ${ }^{6}$ & $12.875 \pm 0.698$ & $1.825 \pm 0.107$ & $1.25 \pm 2.31$ & $1.193 \pm 0.090$ & $46.287 \pm 3.570$ & $1.99 \pm 0.06^{\mathrm{c}, \mathrm{d}}$ \\
\hline Slow, Thick, High MAF ${ }^{7}$ & $12.968 \pm 0.232$ & $1.770 \pm 0.111$ & $1.25 \pm 2.31$ & $1.138 \pm 0.119$ & $44.982 \pm 3.539$ & $2.02 \pm 0.05^{\mathrm{b}, \mathrm{c}}$ \\
\hline Slow, Thin, Low MAF ${ }^{8}$ & $12.648 \pm 0.722$ & $1.810 \pm 0.202$ & $3.16 \pm 3.74$ & $1.186 \pm 0.167$ & $44.099 \pm 5.061$ & $2.00 \pm 0.05^{\mathrm{c}, \mathrm{d}}$ \\
\hline Slow, Thin, High MAF ${ }^{9}$ & $12.833 \pm 0.452$ & $1.746 \pm 0.121$ & $2.50 \pm 2.67$ & $1.124 \pm 0.104$ & $43.294 \pm 3.635$ & $2.01 \pm 0.05^{\mathrm{c}, \mathrm{d}}$ \\
\hline $80 \%$ Lysine $^{10}$ & $12.902 \pm 0.475$ & $1.689 \pm 0.093$ & $1.88 \pm 2.59$ & $1.061 \pm 0.073$ & $43.705 \pm 3.040$ & $2.12 \pm 0.04^{\mathrm{a}}$ \\
\hline Unprocessed Mash $^{11}$ & $12.451 \pm 0.477$ & $1.803 \pm 0.103$ & $5.16 \pm 7.29$ & $1.236 \pm 0.136$ & $43.105 \pm 4.450$ & $1.94 \pm 0.05^{\mathrm{d}}$ \\
\hline Double Pellet $^{12}$ & $12.774 \pm 0.818$ & $1.807 \pm 0.124$ & $3.13 \pm 4.58$ & $1.201 \pm 0.097$ & $47.785 \pm 5.946$ & $2.09 \pm 0.17^{\mathrm{a}, \mathrm{b}}$ \\
\hline ANOVA P value & 0.8377 & 0.7713 & 0.7254 & 0.3929 & 0.4950 & 0.0006 \\
\hline Fisher's LSD & -- & -- & -- & -- & -- & 0.0726 \\
\hline $\mathrm{SEM}^{13}$ & 0.1989 & 0.0468 & 1.3821 & 0.0459 & 1.4867 & 0.0258 \\
\hline \multicolumn{7}{|c|}{ Main effects and interaction probabilities } \\
\hline Production Rate & 0.5931 & 0.7506 & 0.2573 & 0.9132 & 0.8693 & 0.4109 \\
\hline Die Thickness & 0.8759 & 0.6080 & 0.9763 & 0.3936 & 0.0924 & 0.6542 \\
\hline MAF Level & 0.6829 & 0.2323 & 0.6992 & 0.2613 & 0.8263 & 0.3518 \\
\hline $\begin{array}{l}\text { Production Rate } \\
\text { x Die Thickness }\end{array}$ & 0.2253 & 0.9785 & 0.0655 & 0.5768 & 0.8491 & 0.5720 \\
\hline Production Rate $\mathrm{x}$ MAF & 0.5169 & 0.6801 & 0.9921 & 0.6342 & 0.4177 & 0.8735 \\
\hline Die Thickness x MAF & 0.8853 & 0.9203 & 0.6992 & 0.8352 & 0.8168 & 0.9541 \\
\hline $\begin{array}{l}\text { Production Rate } \\
\text { x Die Thickness x } \\
\text { MAF }\end{array}$ & 0.6196 & 0.9856 & 0.9921 & 0.9218 & 0.6342 & 0.5688 \\
\hline \multicolumn{7}{|c|}{ Contrasts } \\
\hline $\begin{array}{l}\text { Unprocessed Mash } \mathrm{x} \\
\text { Factorial Treatments }\end{array}$ & 0.0526 & 0.6681 & 0.0743 & 0.1157 & 0.3521 & 0.0106 \\
\hline $\begin{array}{l}\text { Double Pellet } \mathrm{x} \\
\text { Factorial Treatments }\end{array}$ & 0.6653 & 0.6134 & 0.6772 & 0.3868 & 0.0456 & 0.0059 \\
\hline
\end{tabular}

${ }^{\text {a-d }}$ Values within columns with different superscripts differ $(\mathrm{P} \leq 0.05)$

${ }^{1} \mathrm{BPW}=$ beginning pen weight, $\mathrm{EBW}=$ ending bird weight, $\mathrm{LWG}=$ live weight gain, $\mathrm{FI}=$ feed intake, $\mathrm{FCR}=$ feed conversion ratio

${ }^{2}$ Fast production rate, $44.5 \mathrm{~mm}$ (1.75") die, $0.5 \%$ MAF; $90 \%$ of Cobb's lysine recommendations

${ }^{3}$ Fast production rate, $44.5 \mathrm{~mm}$ (1.75") die, 3\% MAF; $90 \%$ of Cobb's lysine recommendations

${ }^{4}$ Fast production rate, $38.1 \mathrm{~mm}(1.5 ")$ die, $0.5 \% \mathrm{MAF} ; 90 \%$ of Cobb's lysine recommendations

${ }^{5}$ Fast production rate, $38.1 \mathrm{~mm}(1.5$ ") die, 3\% MAF; 90\% of Cobb's lysine recommendations

${ }^{6}$ Slow production rate, $44.5 \mathrm{~mm}(1.75$ ") die, $0.5 \% \mathrm{MAF}$; $90 \%$ of Cobb's lysine recommendations

${ }^{7}$ Slow production rate, $44.5 \mathrm{~mm}$ (1.75") die, $3 \% \mathrm{MAF}$; $90 \%$ of Cobb's lysine recommendations 
${ }^{8}$ Slow production rate, $38.1 \mathrm{~mm}(1.5 ")$ die, $0.5 \% \mathrm{MAF}$; $90 \%$ of Cobb's lysine recommendations

${ }^{9}$ Slow production rate, $38.1 \mathrm{~mm}(1.5$ ") die, 3\% MAF; $90 \%$ of Cobb's lysine recommendations

${ }^{10}$ Fast production rate, $38.1 \mathrm{~mm}$ (1.5") die, 3\% MAF; 80\% of Cobb's lysine recommendations

${ }^{11}$ Unprocessed mash is $90 \%$ of Cobb's lysine recommendations

${ }^{12}$ Double pellet is $90 \%$ of Cobb's lysine recommendations

${ }^{13}$ Standard Error of the Mean, an estimate of the amount that an obtained mean may be expected to differ by chance from the true mean 
Table 4. 23-42d male broiler chick carcass characteristics

\begin{tabular}{|c|c|c|c|c|}
\hline Treatment & $\begin{array}{c}\text { Pectoralis major wt. } \\
\pm \text { SD }(\mathrm{kg})\end{array}$ & $\begin{array}{c}\text { Pectoralis minor wt. } \\
\pm \text { SD }(\mathrm{kg})\end{array}$ & $\begin{array}{c}\text { Total breast wt. } \\
\pm \text { SD (kg) }\end{array}$ & $\begin{array}{c}\text { Breast yield } \\
\pm \mathrm{SD}(\%) \\
\end{array}$ \\
\hline Fast, Thick, Low MAF ${ }^{1}$ & $0.287 \pm 0.037^{\mathrm{a}}$ & $0.050 \pm 0.005$ & $0.338 \pm 0.041^{\mathrm{a}}$ & $16.41 \pm 0.82^{\mathrm{a}}$ \\
\hline Fast, Thick, High MAF ${ }^{2}$ & $0.285 \pm 0.037^{\mathrm{a}}$ & $0.052 \pm 0.006$ & $0.334 \pm 0.038^{\mathrm{a}}$ & $16.02 \pm 0.72^{\mathrm{a}}$ \\
\hline Fast, Thin, Low MAF ${ }^{3}$ & $0.272 \pm 0.024^{\mathrm{a}}$ & $0.049 \pm 0.005$ & $0.321 \pm 0.028^{\mathrm{a}}$ & $15.86 \pm 0.50^{\mathrm{a}}$ \\
\hline Fast, Thin, High MAF ${ }^{4}$ & $0.282 \pm 0.030^{\mathrm{a}}$ & $0.051 \pm 0.007$ & $0.333 \pm 0.037^{\mathrm{a}}$ & $16.38 \pm 0.80^{\mathrm{a}}$ \\
\hline Slow, Thick, Low MAF ${ }^{5}$ & $0.285 \pm 0.024^{\mathrm{a}}$ & $0.053 \pm 0.005$ & $0.338 \pm 0.028^{\mathrm{a}}$ & $15.99 \pm 0.60^{\mathrm{a}}$ \\
\hline Slow, Thick, High MAF ${ }^{6}$ & $0.277 \pm 0.020^{\mathrm{a}}$ & $0.051 \pm 0.004$ & $0.329 \pm 0.023^{\mathrm{a}}$ & $16.14 \pm 0.89^{\mathrm{a}}$ \\
\hline Slow, Thin, Low MAF ${ }^{7}$ & $0.280 \pm 0.010^{\mathrm{a}}$ & $0.051 \pm 0.005$ & $0.330 \pm 0.014^{\mathrm{a}}$ & $16.20 \pm 0.48^{\mathrm{a}}$ \\
\hline Slow, Thin, High MAF $^{8}$ & $0.285 \pm 0.26^{\mathrm{a}}$ & $0.052 \pm 0.005$ & $0.337 \pm 0.031^{\mathrm{a}}$ & $16.33 \pm 1.02^{\mathrm{a}}$ \\
\hline $80 \%$ Cobb Lysine $^{9}$ & $0.234 \pm 0.022^{\mathrm{b}}$ & $0.046 \pm 0.003$ & $0.280 \pm 0.024^{\mathrm{b}}$ & $14.52 \pm 0.62^{b}$ \\
\hline Unprocessed Mash $^{10}$ & $0.291 \pm 0.030^{\mathrm{a}}$ & $0.054 \pm 0.008$ & $0.343 \pm 0.037^{\mathrm{a}}$ & $16.52 \pm 0.93^{\mathrm{a}}$ \\
\hline Double Pellet $^{11}$ & $0.288 \pm 0.017^{\mathrm{a}}$ & $0.053 \pm 0.005$ & $0.341 \pm 0.021^{\mathrm{a}}$ & $16.24 \pm 0.53^{\mathrm{a}}$ \\
\hline ANOVA P value & 0.0063 & 0.2372 & 0.0091 & $<0.0001$ \\
\hline Fisher's LSD & 0.0262 & -- & 0.0298 & 0.6997 \\
\hline SEM $^{12}$ & 0.0093 & 0.0018 & 0.0106 & 0.2485 \\
\hline \multicolumn{5}{|c|}{ Main effects and interaction probabilities } \\
\hline Production Rate & 0.9903 & 0.4042 & 0.8249 & 0.9996 \\
\hline Die Thickness & 0.5563 & 0.5137 & 0.5771 & 0.7810 \\
\hline MAF Level & 0.8613 & 0.4354 & 0.8340 & 0.5872 \\
\hline $\begin{array}{l}\text { Production Rate } \\
\text { x Die Thickness }\end{array}$ & 0.4776 & 0.8748 & 0.5581 & 0.4366 \\
\hline Production Rate $\mathrm{x}$ MAF & 0.7109 & 0.4844 & 0.7106 & 0.8362 \\
\hline Die Thickness x MAF & 0.3447 & 0.4769 & 0.3026 & 0.2365 \\
\hline $\begin{array}{l}\text { Production Rate } \\
\text { x Die Thickness x MAF }\end{array}$ & 0.9764 & 0.6750 & 0.9832 & 0.2122 \\
\hline \multicolumn{5}{|c|}{ Contrasts } \\
\hline $\begin{array}{l}\text { Unprocessed Mash x } \\
\text { Factorial Treatments }\end{array}$ & 0.3457 & 0.1706 & 0.3477 & 0.1845 \\
\hline $\begin{array}{l}\text { Double Pellet } \mathrm{x} \\
\text { Factorial Treatments }\end{array}$ & 0.5313 & 0.4520 & 0.4831 & 0.7763 \\
\hline
\end{tabular}

\footnotetext{
${ }^{\text {a-b }}$ Values within columns with different superscripts differ $(\mathrm{P} \leq 0.05)$

${ }^{1} 0.8$ tonne/h production rate, $44.5 \mathrm{~mm}(1.75$ ") die, $0.5 \%$ MAF; $90 \%$ of Cobb's lysine recommendations

${ }^{2} 0.8$ tonne/h production rate, $44.5 \mathrm{~mm}(1.75$ ") die, $3 \% \mathrm{MAF} ; 90 \%$ of Cobb's lysine recommendations

${ }^{3} 0.8$ tonne/h production rate, $38.1 \mathrm{~mm}(1.5$ ") die, $0.5 \% \mathrm{MAF} ; 90 \%$ of Cobb's lysine recommendations

${ }^{4} 0.8$ tonne/h production rate, $38.1 \mathrm{~mm}(1.5$ ") die, $3 \% \mathrm{MAF} ; 90 \%$ of Cobb's lysine recommendations

${ }^{5} 0.5$ tonne/h production rate, $44.5 \mathrm{~mm}(1.75$ ") die, $0.5 \%$ MAF; $90 \%$ of Cobb's lysine recommendations

${ }^{6} 0.5$ tonne/h production rate, $44.5 \mathrm{~mm}(1.75$ ") die, $3 \% \mathrm{MAF} ; 90 \%$ of Cobb's lysine recommendations

${ }^{7} 0.5$ tonne/h production rate, $38.1 \mathrm{~mm}(1.5$ ") die, $0.5 \% \mathrm{MAF}$; $90 \%$ of Cobb's lysine recommendations

${ }^{8} 0.5$ tonne/h production rate, $38.1 \mathrm{~mm}$ (1.5") die, $3 \% \mathrm{MAF}$; $90 \%$ of Cobb's lysine recommendations

${ }^{9} 0.8$ tonne/h production rate, $38.1 \mathrm{~mm}(1.5$ ”) die, $3 \% \mathrm{MAF} ; \mathbf{8 0 \%}$ of Cobb's lysine recommendations
} 
${ }^{10}$ Unprocessed mash is $90 \%$ of Cobb's lysine recommendations

${ }^{11}$ Double pellet is $90 \%$ of Cobb's lysine recommendations

${ }^{12}$ Standard Error of the Mean, an estimate of the amount that an obtained mean may be expected to differ by chance from the true mean 
Table 5. Furfural content of feed manufactured with various techniques

\begin{tabular}{|l|c|}
\hline Treatment & Furfural \pm SD (nanomoles/g) \\
\hline Fast, Thick, Low MAF & $1.40 \pm 0.28$ \\
\hline Fast, Thick, High MAF & $1.24 \pm 0.30$ \\
\hline Fast, Thin, Low MAF & $1.11 \pm 0.25$ \\
\hline Fast, Thin, High MAF & $1.47 \pm 0.15$ \\
\hline Slow, Thick, Low MAF & $1.67 \pm 0.12$ \\
\hline Slow, Thick, High MAF & $1.45 \pm 0.32$ \\
\hline Slow, Thin, Low MAF & $1.23 \pm 0.28$ \\
\hline Slow, Thin, High MAF & $1.24 \pm 0.15$ \\
\hline $80 \%$ Lysine & $1.30 \pm 0.20$ \\
\hline Unprocessed Mash & $1.46 \pm 0.32$ \\
\hline Double Pelleted & $1.21 \pm 0.32$ \\
\hline ANOVA P-value & 0.1497 \\
\hline SEM ${ }^{1}$ & 0.1275 \\
\hline & Contrasts \\
\hline Unprocessed Mash x Factorial & 0.4239 \\
\hline Double Pelleted x Factorial & \\
\hline
\end{tabular}

${ }^{1}$ Standard Error of the Mean, an estimate of the amount that an obtained mean may be expected to differ by chance from the true mean 
Table 6. True digestibilities of amino acids in broiler feed manufactured with various techniques ${ }^{1}$

\begin{tabular}{|c|c|c|c|c|c|c|c|c|c|c|c|c|}
\hline \multirow[b]{2}{*}{ Treatment } & \multicolumn{12}{|c|}{ True Digestibility $(\mathrm{W} / \mathrm{W} \%) \pm \mathrm{SEM}^{2}$} \\
\hline & Alanine & $\begin{array}{c}\text { Aspartic } \\
\text { Acid }\end{array}$ & Cysteine & $\begin{array}{c}\text { Glutamic } \\
\text { Acid }\end{array}$ & Isoleucine & Leucine & Lysine & Methionine & Proline & Threonine & Valine & Total \\
\hline $\begin{array}{l}\text { Unprocessed } \\
\text { Mash }\end{array}$ & $\begin{array}{l}89.53 \\
\pm 1.43\end{array}$ & $\begin{array}{l}89.04 \\
\pm 0.97\end{array}$ & $\begin{array}{l}87.41 \\
\pm 2.50\end{array}$ & $\begin{array}{l}93.49 \\
\pm 0.66\end{array}$ & $\begin{array}{l}92.16 \\
\pm 1.02\end{array}$ & $\begin{array}{l}89.64 \\
\pm 0.85\end{array}$ & $\begin{array}{l}90.00 \\
\pm 1.17\end{array}$ & $\begin{array}{l}95.54 \\
\pm 0.78\end{array}$ & $\begin{array}{l}92.81 \\
\pm 1.16\end{array}$ & $\begin{array}{l}93.18 \\
\pm 1.46\end{array}$ & $\begin{array}{l}92.68 \\
\pm 1.23\end{array}$ & $\begin{array}{l}86.04 \\
\pm 2.71\end{array}$ \\
\hline $\begin{array}{l}\text { Double } \\
\text { Pellet }\end{array}$ & $\begin{array}{l}88.41 \\
\pm 1.53 \\
\end{array}$ & $\begin{array}{l}88.87 \\
\pm 1.03\end{array}$ & $\begin{array}{l}87.02 \\
\pm 2.67\end{array}$ & $\begin{array}{l}93.58 \\
\pm 0.71\end{array}$ & $\begin{array}{l}90.56 \\
\pm 1.09\end{array}$ & $\begin{array}{l}88.94 \\
\pm 0.91\end{array}$ & $\begin{array}{l}89.32 \\
\pm 1.25\end{array}$ & $\begin{array}{l}95.01 \\
\pm 0.84\end{array}$ & $\begin{array}{l}92.17 \\
\pm 1.24\end{array}$ & $\begin{array}{l}92.38 \\
\pm 1.56\end{array}$ & $\begin{array}{l}90.41 \\
\pm 1.31\end{array}$ & $\begin{array}{l}87.06 \\
\pm 2.89\end{array}$ \\
\hline $\begin{array}{l}0.8 \text { tonne } / \mathrm{h}, \\
38.1 \mathrm{~mm} \text {, } \\
3 \% \mathrm{MAF}\end{array}$ & $\begin{array}{l}86.13 \\
\pm 1.53\end{array}$ & $\begin{array}{l}86.61 \\
\pm 1.03\end{array}$ & $\begin{array}{l}84.70 \\
\pm 2.67\end{array}$ & $\begin{array}{l}92.14 \\
\pm 0.71\end{array}$ & $\begin{array}{l}90.12 \\
\pm 1.09\end{array}$ & $\begin{array}{l}88.27 \\
\pm 0.91\end{array}$ & $\begin{array}{l}87.36 \\
\pm 1.25\end{array}$ & $\begin{array}{l}93.85 \\
\pm 0.84\end{array}$ & $\begin{array}{l}91.45 \\
\pm 1.24\end{array}$ & $\begin{array}{l}89.65 \\
\pm 1.56\end{array}$ & $\begin{array}{l}89.76 \\
\pm 1.31\end{array}$ & $\begin{array}{l}84.92 \\
\pm 2.89\end{array}$ \\
\hline $\begin{array}{l}0.5 \text { tonne } / \mathrm{h}, \\
44.5 \mathrm{~mm} \text {, } \\
1 \% \mathrm{MAF}\end{array}$ & $\begin{array}{l}90.63 \\
\pm 1.43\end{array}$ & $\begin{array}{l}89.74 \\
\pm 0.96\end{array}$ & $\begin{array}{l}89.07 \\
\pm 2.50\end{array}$ & $\begin{array}{l}94.60 \\
\pm 0.66\end{array}$ & $\begin{array}{l}92.64 \\
\pm 1.02\end{array}$ & $\begin{array}{l}90.22 \\
\pm 0.85\end{array}$ & $\begin{array}{l}90.58 \\
\pm 1.17\end{array}$ & $\begin{array}{l}96.09 \\
\pm 0.78\end{array}$ & $\begin{array}{l}94.10 \\
\pm 1.16\end{array}$ & $\begin{array}{l}93.21 \\
\pm 1.46\end{array}$ & $\begin{array}{l}92.73 \\
\pm 1.23\end{array}$ & $\begin{array}{l}93.32 \\
\pm 2.71\end{array}$ \\
\hline $\begin{array}{l}\text { ANOVA } \\
\mathrm{P} \text { value }\end{array}$ & 0.4201 & 0.4046 & 0.8051 & 0.2456 & 0.2537 & 0.4751 & 0.4614 & 0.3409 & 0.4111 & 0.2735 & 0.2416 & 0.2193 \\
\hline
\end{tabular}

${ }^{1}$ Each figure represents the mean of eight cecectomized roosters

${ }^{2}$ Standard Error of the Mean, an estimate of the amount that an obtained mean may be expected to be differ by chance from the true mean 